\title{
Merkeziyetsiz Finans (Defi) Faaliyetlerinin İzinsiz Bankacılık Faaliyetinde Bulunma Suçu Bakımından Değerlendirilmesi
}

\author{
Considerations on Decentralized Financial (Defi) Activities in Terms of \\ Unauthorized Banking Crime
}

Serkan Meraklı*

\section{öz}

Merkeziyetsiz finans alanı son yıllarda oldukça hızlı bir şekilde gelişmekte olup klasik finans araçlarına alternatif teşkil etme iddiası ile finans alanında oldukça köklü bir değişimin eşiğinde olduğumuz kanaatini uyandırmaktadır. Bu denli önemli bir değişimin eşiğindeyken merkeziyetsiz finans kavramının hukuki açıdan ne anlam ifade ettiğinin; merkeziyetsiz finans araçlarının neler olduğunun ortaya konulması ve bunların hukuki açıdan değerlendirilmesi önem taşımaktadır. Öte yandan henüz merkeziyetsiz finans araçları ile ilgili detaylı bir hukuki düzenleme bulunmamasına rağmen bu faaliyetlerin Bankacılık Kanunu’ndaki izinsiz bankacılık suçu bakımından değerlendirilmesi özellikle kanunilik ilkesi bakımından büyük bir öneme sahiptir. Bu değerlendirme merkeziyetli finans ile merkeziyetsiz finans araçlarının niteliklerinin daha iyi anlaşılmasına katkı sunabilir.

Anahtar Kelimeler: Blokzincir, Akıllı Kontrat, Merkeziyetsiz Finans, Likidite Madenciliği, Staking

\section{ABSTRACT}

As a rapidly developing notion and an alternative to conventional financial instruments in recent years, decentralized finance has given the idea that a radical evolution in field of finance is inevitable. At the dawn of such a remarkable change the legal meaning of decentralized finance and the evaluation of the decentralized financial instruments are of a great importance. Besides, examination on decentralized financial instruments in connection with unauthorized banking crime prescribed by the Banking Code in terms of principle of legality is of a great importance either. Such an evaluation is able to make contribution for the better understanding of the characteristics of centralized finance and decentralized financial instruments.

Keywords: Blockchain, Smart Contrats, Decentralized Finance (DeFi), Yield Farming, Staking

* $\quad$ Dr. Öğr. Üyesi, Dokuz Eylül Üniversitesi Hukuk Fakültesi, Ceza ve Ceza Muhakemesi Hukuku Anabilim Dalı, ORCID: 0000-0003-4414-5466.

Sorumlu Yazar/Correspondence Author: Serkan Meraklı

E-posta/E-mail: serkan.merakli@deu.edu.tr

Geliş Tarihi/Received: $\quad$ 17.09.2021

Kabul Tarihi/Accepted:

05.11 .2021 


\section{GíRiş}

Merkeziyetsiz finans kavramı son yıllarda ortaya çıkan, klasik finans dünyasını yeniden şekillendirmeyi amaçlayan ve merkezi nitelik taşıyan finans araçlarının sahip olduğu dezavantajlı yönleri ortadan kaldırmayı hedefleyen bir kavramdır. Çalışmanın konusu belirlenirken bir üst kavram olarak merkeziyetsiz finans kavramını ve araçlarını hukuki açıdan değerlendiren çalışmaların Türk hukukunda neredeyse hiç bulunmadığı; bu alanda yapılan çalışmalarda çoğu zaman sadece blokzincir ve kripto paraların ele alınması ile yetiniliyor olmasından hareket edilmiştir. Bu bakımdan çalışmada öncelikle merkeziyetsiz finans kavramının taşıdı̆̆ı anlam ve sahip olduğu uygulama alanları ele alınacaktır. Konunun teknolojik boyutu oldukça derin bir niteliğe sahip olduğundan bir hukukçu olarak teknik açıklamalara sınırlı ve ölçülü derecede yer verilecek olup bu araçların hukuki açıdan ifade ettikleri anlama yoğunlaşılmaya çalışılacaktır.

Bu çalışmada merkeziyetsiz finans kavramı ve araçları hakkında okuyucularda bir fikir uyandırmak amaçlanmış olup 5411 sayılı Bankacılık Kanunu m. 150/1'deki izinsiz bankacılık faaliyetinde bulunma suçu bakımından bir değerlendirme yapılmak istenmiştir. Belki ilk bakışta merkeziyetsiz finans alanındaki işlemlerin Bankacılık Kanunu m. 150/1'de düzenlenen suç tipini oluşturmayacağı düşünülebilir; fakat suç genel teorisinin kurumları üzerinden bir inceleme yapılarak bu düşüncenin yerinde olup olmadığı sistematik bir şekilde ortaya konulmaya çalışılacaktır. Öte yandan merkeziyetsiz finans alanında gerçekleştirilen işlemlerin pek çok suç bakımından değerlendirilmesi mümkündür. Fakat çalışmanın olası bütün suçlar ölçüsünde geniş tutulması halinde bunun bir makalenin boyutlarını aşacağı açıktır. Bu bakımdan çalışmanın konusu sadece izinsiz bankacılık faaliyetinde bulunma suçu ile sınırlı tutulacaktır. Bunun yanı sıra çalışmada, merkeziyetsiz finans araçlarının, getiriliş amaçları doğrultusunda kullanılmaları halinde bu faaliyetlerin izinsiz bankacılık faaliyetinde bulunma suçunu oluşturup oluşturmayacağı ele alınacaktır. Dolayısıyla son günlerde uygulamada çok sık ortaya çıkmaya başlayan dolandırıcılık ya da bilişim suçları gibi eylemler bu çalışmanın konusunu oluşturmamaktadır.

Merkeziyetsiz finans araçları hakkında hukukumuzda genel düzenleyici işlem olarak sadece kripto paraların bir ödeme aracı olarak kullanılmasını yasaklayan Yönetmelik ${ }^{1}$ bulunmakta olup bunun ötesine geçen ve merkeziyetsiz finans araçlarının tamamını kapsamayı hedefleyen genel bir düzenleme bulunmamaktadır. Bu itibarla çalışmada, bu faaliyetlerin, hukukumuzda bankacılık sistemini ve araçlarını ceza hukuku yoluyla korumayı amaçlayan izinsiz bankacılık faaliyetinde bulunma suçu karşısındaki konumu değerlendirilecektir. Bu değerlendirmede merkeziyetsiz finans araçlarının bankacılık sistemine bir alternatif oluşturmayı amaçladığı ve bankacılık sistemini kökten değiştirmeyi hedeflediği göz önünde tutulacaktır.

Bu arka plan göz önünde tutulmak suretiyle çalışmada ilk olarak merkeziyetsiz finans kavramının anlamı ve merkeziyetli finans kavramından farkı ele alınacak olup ardından merkeziyetsiz finans araçları incelenecektir. Daha sonra ise merkeziyetsiz finans alanındaki işlem türlerinin neler olduğuna yer verilecek ve ülkemizdeki merkeziyetsiz finans alanındaki hukuki duruma değinildikten sonra

1 Ödemelerde Kripto Varlıkların Kullanılmamasına Dair Yönetmelik, RG 16.04.2021/ 31456. 
merkeziyetsiz finans alanındaki işlemlerin izinsiz bankacılık faaliyetinde bulunma suçunu oluşturup oluşturmayacağı suç genel teorisi bakımından değerlendirilecektir.

\section{MERKEZIYETSIZ FINANS (DeFi) KAVRAMI}

\section{A. GENEL OLARAK}

Merkeziyetsiz finans (Decentralized finance - DeFi) kavramı en temel anlatımla, belirli bir otoritenin sunduğu somut bir güvenceye bağlı olmaksızın şekillenen bir finans sistemi olarak tanımlanabilir² Burada merkeziyetsiz finans kavramını daha iyi anlayabilmek için öncelikle merkeziyetli finans (Centralized finance - CeFi) kavramının ortaya konması faydalı olur. Çünkü merkeziyetsiz finans kavramının, merkeziyetli finans yapılanmasının eleştirilen çeşitli yönlerine bir meydan okuma olarak ortaya çıktığı söylenebilir. Merkeziyetli finans yapılanmasının temelinde çoğu zaman bankalar ve finans kuruluşları yer almaktadır. Gerçekten finansal hayatta yapılan çoğu işleme bankalar ve diğer finans kuruluşları aracılık etmektedir. Bu yapının ortaya çıkışı aslında hem finansal hayatın gelişmesini sağlamış, hem de finansal hayatın hızlı ve güvenli bir şekilde işleyebilmesini mümkün kılmıştır. Ancak 21'inci yüzyıla gelindiğinde özellikle internet ve yazılım teknolojilerindeki baş döndürücü gelişmeler çoğu alanda olduğu gibi finans alanında da köklü değişiklik arayışlarını beraberinde getirmiştir. $\mathrm{Bu}$ arayış içerisinde değişiklik düşünülen kurumların başında bankalar yer almıştır. Merkeziyetsiz finans yapısı incelendiğinde de bu yapının özellikle bankacılık kurumunun değişimi ve dönüşümüne yol açacağı ve adeta bankaların finans alanındaki "tekel”lerinin yıkılmasını beraberinde getireceği söylenebilir. Bu açılamalar ş̧ığında finans alanında bir çağ değişiminin eşiğinde olunduğu görülebilir. Bu noktada değişen çağın bu yeniliklerine sırt çevirmekten ziyade korkuya kapılmadan ona ayak uydurmak en faydacı ve akılcı yol olacaktır.

\section{B. MERKEZIYETLI FINANS (CeFi) - MERKEZIYETSIZ FINANS (DeFi) KAVRAMLARI}

Merkeziyetsiz finans sistemi, bir merkezi otoriteden bağımsız faaliyet gösterilen bir finans sistemini ifade eder ve buna uygun finans araçlarını bünyesinde barındırır. Bu tür bir merkeziyetsizliği sağlayacak en önemli araç ise blokzincir teknolojisidir. Merkeziyetli finans (CeFi) sisteminde ise bu işlevi çoğu zaman bankalar yerine getirmektedir. Merkeziyetli finans sisteminde kişiler paralarını bankada açacakları hesaba yatırırlar ve bu şekilde mevduat faizi elde edebilirler. Bunun dışında bir başkasına para göndermek istediğinizde bankadaki hesabınızdan istediğiniz tutarı bir başkasının hesabına havale yapabilirsiniz. Ayrıca belirli bir miktar paraya ihtiyaç duyduğunuzda bankadan kredi çekebilirsiniz. Bu işlemlerin tamamında banka adıverilen kuruma güven duyduğunuz için paranızı bu kuruma yatırmaktan, paranızı bu kurum aracılığıyla bir başkasına göndermekten ya da bu kuruma borçlanmaktan çekinmezsiniz ${ }^{3}$. Çünkü banka ile aranızdaki ilişkinin esaslarını belirleyen ve güvence altına alan hukuk kuralları bulunur ve bunun yanı sıra bankaları denetleyen bir

2 Deniz Alp İmamoğlu, Kripto Para Birimleri ve Türk Hukukunda Düzenlenmesi, (2. Baskı, Seçkin 2021) 87.

3 Ceyhun Yakup Özkardeş, 'Decentralized Finance: Was hinter dem Begriff steckt' (t3n, 11.11.2019) <https://t3n.de/news/ decentralized-finance-begriff-1216522/> Erişim Tarihi: 24.05.2021. 
otorite olarak ülkemizde BDDK ve diğer ülkelerde de benzer kurumlar bulunur. Bu noktada banka ile müşterileri arasındaki ilişkiyi güvence altına alan bir Yönetmelik hükmünden bahsedilebilir. Gerçekten bu yönetmeliğe göre, mevduat hesaplarının bugün için 150.000 TL’ye kadar olan kısmı TMSF vasıtasıyla sigorta altına alınmaktadır ${ }^{4}$. Bunun haricinde hisse senetlerinin işlem gördüğü menkul kıymetler borsaları da merkeziyetli bir finans yöntemi olarak anılabilir. Örneğin Borsa İstanbul'da bir işlem yaptığınızda ani düşüş ya da yükselişlerde Borsa İstanbul yönetimi tarafından devre kesici uygulamaları gerçekleştirilmektedir. Buna benzer şekilde açığa satış yasağı gibi uygulamalar da söz konusu olabilecek diğer yöntemlerdir. Bu tür faaliyetler, manipülasyonların önüne geçilebilmesini merkezi bir otorite aracılığıyla sağlamaktadır. Ayrıca Sermaye Piyasası Kurulu'nun (SPK) da bu çerçevede pek çok yetki ve görevi bulunmaktadır. Buraya kadar anılan faaliyetler merkezi bir yapıdadır; çünkü mevduat hesabınızla ilgili olarak veya gerçekleştirdiğiniz havale işlemi ile ilgili ya da kullandığınız kredi ile ilgili bir sorun yaşadığınız takdirde karşınızda hukuken muhatap alabileceğiniz ve tek başına bu sorun hakkında işlem yapabilecek bir kurum bulunmaktadır. Benzer bir durum hisse senetlerinde de yukarıda anıldığı üzere söz konusudur ${ }^{5}$. İşte bu noktada merkeziyetli finans ile merkeziyetsiz finans arasındaki fark ortaya çıkmaktadır.

Merkeziyetsiz finans yönteminde banka kurumu aracı olmaktan çıkartılmakta ve işlem yapmak isteyen her bir kişi adeta kendisi bir bankaya dönüşmektedir. Aracılık edecek bir banka olmadan bir başkasına para havale etmek ya da bir başkasına borç vermek veya bir başkasından borç almak ya da merkeziyetli finansın araçlarından biri olan mevduat hesabı açılmasına benzer bir nitelik taşıyan faiz elde etmek amacıyla paranın kilitlenmesi merkeziyetsiz finans kapsamında mümkündür6 Merkeziyetsiz finans çerçevesinde bu işlemleri yapabilmek için eğer maddi kaynağınız mevcut ise internet bağlantınızın bulunması yeterli olacaktır ${ }^{7}$. Dolayısıyla merkeziyetsiz finansın özellikle finansal altyapı açısından geri kalmışülkeler bakımından büyük bir avantaj olacağı̈ öne sürülmektedir ${ }^{8}$. Merkeziyetsiz finans araçlarının getirilerinin merkeziyetli finans araçlarının getirilerine oranla daha yüksek olabileceği; örneğin aşağıda daha ayrıntılı yer verilecek olan staking adı verilen bir kripto para biriminin belirli bir miktarda sisteme kilitlenmesi ve belirli süreler sonunda buradan faiz getirisi elde edilmesinin herhangi bir bankaya yatırılan mevduat tutarına uygulanan faiz oranından çok daha fazla olabileceği ya da reel anlamda daha fazla getiri sunabileceği öne sürülmektedir 9 .

4 Sigortaya Tabi Mevduat Ve Katılım Fonları İle Tasarruf Mevduatı Sigorta Fonunca Tahsil Olunacak Primlere Dair Yönetmelik (7/11/2006 tarih, R.G. 26339) m. 4/ 1'e göre “Tasarruf mevduatı hesaplarının anaparaları ile bu hesaplara ilişkin faiz reeskontları toplamının,

b) Katılma hesapları birim hesap değerlerinin ve özel cari hesapların her bir gerçek kişi için 150 bin Türk Lirasına kadar olan kısm sigorta kapsamindadır."

5 Sébastien Bonset, 'Hype um Defi: Was du über Decentralized Finance wissen musst und wie du profitierst'( $($ 3nn, 28.05.2021) $<$ https://t3n.de/news/defi-erklaert-das-steckt-hinter-decentralized-finance-1356901/,> Erişim Tarihi: 24.05.2021.

6 Turan Sert, 'Sorularla Blockchain' (Bankalararası Kart Merkezi 2015) <https://bkm.com.tr/wp-content/uploads/2015/06/ Sorularlablockchain.pdf> Erişim Tarihi 30.05.2021, 17.

7 İbid 17.

8 Ceyhun Yakup Özkardeş, 'Decentralized Finance: Was hinter dem Begriff steckt' (t3n, 11.11.2019) <https://t3n.de/news/ decentralized-finance-begriff-1216522/> Erişim Tarihi: 24.05.2021.

9 Ceyhun Yakup Özkardeş, 'Decentralized Finance: Was hinter dem Begriff steckt' (t3n, 11.11.2019) <https://t3n.de/news/ decentralized-finance-begriff-1216522/> Erişim Tarihi: 24.05.2021. Bu tür bir tespite Euro bölgesindeki sıfıra yakın faiz politikasının yol açtı̆̆ı söylenebilir. 
Ancak her bir kripto para birimi bakımından farklı faiz oranları söz konusu olduğundan ve ayrıca kripto paralardaki dalgalanmaların çok yüksek olmasından ötürü bu staking işleminin getirisinin, merkeziyetli finanstaki mevduat faizinin getirisinden yüksek olduğunun genel geçer bir tespit olarak söylenebilmesi kanımızca mümkün değildir.

Merkeziyetsiz finansın, merkeziyetli finansa göre sahip olduğu avantajlar şu şekilde sıralanabilir:

- Aracı kurumlar ortadan kaldırılmaktadır ${ }^{10}$.

- Aracı kurumların ortadan kalkmasının bir sonucu olarak özellikle havale işlemlerinde bankaya ödenen komisyonlar ortadan kalkmaktadır.

- Staking gibi işlemlerde elde edilen faiz oranları bankaların sunduğu mevduat faizlerine göre daha yüksek olabilmektedir.

Merkeziyetsiz finansın, merkeziyetli finansa göre barındırdığı dezavantajlar ise merkeziyetsiz finans işlemi yapmak isteyen bir kişinin ya kendi blokzincirini ve yazılımını oluşturması gerekmekte ya da bir DeFi platformuna güvenerek kripto paralarını bu platform üzerinden işleme tâbi tutması gerekmektedir ${ }^{11}$.

\section{BLOKZINCIR (TEKNOLOJISI) KAVRAMI}

\section{ANLAMI}

Öncelikle belirtmek gerekir ki blokzincir kavramından ziyade blokzincir teknolojisi kavramından bahsetmek daha doğru bir tercih olacaktır. Öyle ki, çeşitli kullanım alanlarında pek çok farklı uygulamacı tarafından kendi ihtiyaçlarını karşılamak amacıyla bu teknolojiye başvurulması ve bu teknolojinin geliştirilmesi söz konusu olmaktadır ${ }^{12}$.

Blokzincir kavramı, birbiriyle uzaktan bağlı makinelerin belirli işlemleri (örneğin ticari işlemler ya da ödeme işlemleri) ortak bir mutabakat çerçevesinde değiştirilemez biçimde tuttukları bir protokol ya da diğer bir deyişle defter sistemi anlamını taşımaktadır ${ }^{13}$. Blokzincir teknolojisi, verilerin

10 Burada aracı kurumların kaldırılması ile ifade edilmek istenen Ethereum ağı gibi ağlar üzerinden gerçekleştirilen merkeziyetsiz işlemlerdir. Dolayısıyla merkeziyetli kripto para borsaları burada ifade edilmemektedir. Kaldı ki merkeziyetli kripto para borsalarının doğrudan merkeziyetsiz finans aracı olduğunu söyleyebilmenin mümkün olup olmadığı tartışmalıdır. Çünkü merkeziyetli kripto para borsalarında merkeziyetsiz bir işlem yapılmamakta olup bir merkezin aracılığı ile kripto paraların alınıp satılması sağlanmaktadır. Dolayısıyla esasen bu faaliyetin bankaların kambiyo işlemlerinden farklı olduğu söylenemez. Fakat bu açılama merkeziyetsiz kripto para borsaları için geçerli değildir.

11 Ceyhun Yakup Özkardeş, 'Decentralized Finance: Was hinter dem Begriff steckt' (t3n, 11.11.2019) <https://t3n.de/news/ decentralized-finance-begriff-1216522/> Erişim Tarihi: 24.05.2021.

12 Stefan Möllenkamp and Leonid Shmatenko, 'Blockchain und Kryptowährungen' in Thomas Hoern, Ulrich Sieber ve Bernd Holznagel (eds), Handbuch Multimedia-Recht (55th edn, Beck 2021), Teil 13.6, kenar no (kn) 1.

13 Joachim Schrey and Thomas Thalhofer, 'Rechtliche Aspekte der Blockchain' (2017) NJW 1431; Sert (n 6) 49; Murat Volkan Dülger, 'Blockchain ve Hukuksal Kullanım Alanları' (2019) Hukuk ve Daha Fazlası Dergisi, 42 - 43; Umut Balc1, 'Kripto Paraların Ceza Hukuku Boyutu ve Türk Mevzuatındaki Muhtemel Düzenlenme Yeri'(2021) 155 Türkiye Barolar 
merkezi bir yer üzerinden değil bireysel aktörlerin kendileri arasında (İng. Peer to peer) gönderildiği bilgisayar protokollerine ve iletişim ağlarına dayanmaktadır ${ }^{14}$. Blokzincir teknolojisinde her ilişki ve birbiri ardı sıra gerçekleşen her işlem, bireysel aktörler arasında kriptografik yöntemle özel olarak dijital bir defterde güvence altına alınmaktadır ${ }^{15}$. Bu defterde her bir işlem bloklara kaydedilmekte ve birbiri ardına dizilmektedir. Birbiri ardına dizilen bu bloklar kriptografik yöntemlerle şifrelenerek dijital parmak izleri ile birbirine zincirlenmektedir. Sisteme eklenen her bir blok kendisinden önce gelen parmak izini içermektedir. Bu sayede bloklar üzerindeki her bir değişiklik kaydedilmekte ve sistemdeki manipülasyonlar önlenebilmektedir. Bu şekilde oluşan dijital zincir sisteme kayıtlı bilgisayarların tamamına yayılmakta olup bu sayede blokzincir sistemi tek bir merkezde tutulan bir kayıt değil; aksine dağınık şekilde pek çok bilgisayarda yer alan bir kayıt sistemi oluşturmaktadır ${ }^{16}$. Blokzincir vasıtasıyla eşler arası (Peer to peer) şekilde kurulan ağ tüm bilgisayarları birbirine bağlamakta ve her bir bilgisayar bu sistemde eşit muamele görmektedir. Bu sayede bu sisteme katılan her bilgisayar hem sistemdeki hizmetlerden faydalanmakta hem de sistemde hizmet sunabilmektedir ${ }^{17}$. Blokzincir teknolojisinin özelliklerini ortaya koyan dört ana unsur eşler arası ağ, dağınık defter sistemi, mutabakat mekanizması ve kriptografi sistemidir ${ }^{18}$. Blokzincir teknolojisi üzerinde pek çok hukuki işlem türünün gerçekleştirilmesi mümkündür ${ }^{19}$. İlerleyen y1llarda bu işlemlerin çeşitlerinin ve yaygınlığının artacağı düşünülmektedir. Aşağıda blokzincir uygulamalarının bazıları kısaca açıklanacaktır.

\section{BLOKZINCIR UYGULAMALARI}

\section{A. AKILLI KONTRATLAR}

Akıllıkontratlar, kaynakkodlarında, belirliolaylar meydana geldiğindeveya belirligirdileryapıldığında önceden tanımlanmış eylemleri veya bir veri kaydındaki değişiklikleri gerçekleştirmelerini sağlayan değişmez kurallar içeren bilgisayar protokolleridir ${ }^{20}$. Blokzincir teknolojisi, olayları zamansal açıdan belgeleyebildiği ve malvarlığı değerlerini farklı hak sahipleri veya yetkili kişiler arasında tasnif etmek için token adı verilen araçları kullanabildiğinden, bu tür akıllı kontratların suretini çıkarmak için de

Birliği Dergisi 203, 207; Mete Tevetoğlu, 'Ethereum Ve Akıllı Sözleşmeler' (2021) 12(1) İnönü Üniversitesi Hukuk Fakültesi Dergisi 193, 195.

14 Gunnar Groh, 'Blockchain' in Klaus Weber (ed), Creifelds Kompakt - Rechtswörterbuch, (4th edn, Beck 2021) <www. beck-beckonline.de> Erişim Tarihi: 06.06.2021); Möllenkamp and Shmatenko , (n 12) Teil 13.6, kn. 3; Nicolas Hohn Hein and Günter Barth, 'Immaterialgüterrechte in der Welt von Blockchain und Smart Contract' (2018) GRUR 1089; Cristoph Kumpan, 'WpHG' in Eberhard Schwark ve Daniel Zimmer (eds), Kapitalmarktrechts-Kommentar (5 ${ }^{\text {th }}$ edn, Beck 2020) \$2 kn. 82.

15 Gunnar Groh, 'Blockchain' in Klaus Weber (ed), Creifelds Kompakt - Rechtswörterbuch, (4th edn, Beck 2021) <www. beck-beckonline.de> Erişim Tarihi: 06.06.2021); Möllenkamp and Shmatenko, (n 12) Teil 13.6 kn. 3; Balc1 (n 13 ) 207.

16 Kumpan (n 14) \$2 kn. 82; Schrey and Thalhofer (n 13) 1431.

17 Möllenkamp and Shmatenko, (n 12) Teil 13.6, kn. 3 dipnot 2. Ayrıca bakınız (bkz) Schrey and Thalhofer (n 13 ) 1431.

18 Melih Sefa Yavuz, 'Ekonomide Dijital Dönüşüm: Blockchaın Teknolojisi ve Uygulama Alanları Üzerine Bir İnceleme' (2019) 4(1) Finans Ekonomi ve Sosyal Araştırmalar Dergisi 15, 16.

19 Bu işlem türleri hakkında bkz. Dülger (n 13) $45 \mathrm{vd}$.

20 Möllenkamp and Shmatenko, (n 12) Teil 13.6, kn. 15; Sert (n 6) 127. 
uygundur ${ }^{21}$. Bu nedenle akıllı kontrat kavramı çoğu zaman blokzincir teknolojisi ile bağlantılı olarak ele alınmaktadır. Blokzincir teknolojisi yukarıda da belirtildiği üzere merkezî olmayan bir mutabakat mekanizmasına dayanan ve veri depolamaya imkan veren bir veri bankası organizasyonudur ${ }^{22}$. Akıllı kontratların blokzincir teknolojisi üzerine taşınması teknik açıdan her ne kadar zorunlu olmasa da blokzincir teknolojisi, dijital işlemlerin doğrudan yapılmasına imkan verdiğinden, akıllı kontratların etkin şekilde kullanımı için oldukça önemli bir altyapı teşkil etmektedir ${ }^{23}$. Blokzincir teknolojisi hem program kodlarını hem de tutulan kayıtların manipülasyonlara karşı korunmasını sağlamaktadır. Program kodları, belirlenen adımların uygulanması için teknik bir garantiyi beraberinde getirmektedir. Merkezi sunucuların varlığına dayanan klasik yapıların aksine, sözleşmenin taraflarını ödeme yapılamama riskinden kurtaran belirli bir üçüncü kişiye ihtiyaç kalmamaktadı2 ${ }^{24}$.

Akıllı kontrat kavramı hukuken tanımlanmamış olsa da şu şekilde tanımlanması mümkündür: Kural olarak dijital olarak doğrulanabilen olayları işleyen ve bundan hareketle hukuki açıdan önem taşıyan hareketlerin gerçekleştirilmesini sağlayan ya da belgeleyen yazılımlardır ${ }^{25}$.

Öte yandan akıllı kontrat kavramı, çoğu zaman sözleşme kavramı ile karıştırılmaktadır. Her ne kadar akıllı kontrat kavramında kontrat terimi bulunuyor olsa da bunlar özü itibariyle hukuki anlamda birer sözleşme teşkil etmezler. Çünkü akıllı kontratlar kapsamında sadece, bir sözleşmenin çözmesi gereken otomatikleştirilmiş prosedürler ya da önceden bir sözleşme ile belirlenmiş eylemler söz konusu olmaktadır. Diğer bir deyişle akıllı kontratlar sadece önceden akdedilmiş bir sözleşmenin yerine getirilmesi anlamında bir icra aşaması teşkil eder ${ }^{26}$. Akıllı sözleşmelerin amacı, program kodlarını kullanarak sözleşmelerin yürütülmesini otomatikleştirmektir ${ }^{27}$. Akıllı kontratlar üzerinden, daha önce kurulan ve uygulanma aşamasına geçilen sözleşmenin maddi hükümleri uygulanı ${ }^{28}$. Fakat bununla birlikte akıllı kontratın blokzincir içerisine sokulması ya da diğer bir deyişle programlanması bir sözleşmenin kurulması anlamını taşıyabilir² ${ }^{29}$.

Akıllı kontrat kapsamında sözleşmenin bütünü ya da belirli bir kısmı - bir sözleşmenin uygulanması için gerekli olduğu takdirde - oracle adı verilen veri kaynaklarıyla (örneğin borsa değerleri, üretim sayıları, hava durumu verileri gibi) gerçek dünyadaki olayları birbirine bağlayabilen bir yazılıma eklenmektedir ${ }^{30}$. Belirli sözleşme şartları bir olayın ortaya çıkmasıyla yerine getirilmiş ya da belirlenen sözleşme yükümlülükleri ihlal edilmiş olursa, akıllı kontrat adı verilen yazılım, öngördüğg̈ hukuki

21 Möllenkamp and Shmatenko, (n 12) Teil 13.6, kn. 15.

22 Stefan Möllenkamp and Nikolas Guggenberger, 'Blockchain und Kryptowährungen' in Thomas Hoern, Ulrich Sieber ve Bernd Holznagel (eds), Handbuch Multimedia-Recht (55th edn, Beck 2021) Teil 13.7, kn. 2.

23 Möllenkamp and Guggenberger, (n 22) Teil 13.7, kn. 2.

24 ibid kn. 2.

25 ibid kn. 1.

26 Möllenkamp and Shmatenko, (n 12) Teil 13.6, kn. 72. Ayrıca bkz. Sert (n 6) 127.

27 Hohn-Hein and Barth, (n 14) 1093.

28 Möllenkamp and Shmatenko, (n 12) Teil 13.6, kn. 72; Hohn-Hein and Barth, (n 14) 1093.

29 Möllenkamp and Shmatenko, (n 12) Teil 13.6, kn. 72.

30 Hohn-Hein and Barth, (n 14) 1093. 
sonuçları kendiliğinden devreye sokmaktadır ${ }^{31}$. Akıllı kontratların bir blokzincire aktarılması, elektronik sözleşme şartlarının devreye sokulmasının (örneğin mutabık kalınan lisans ücreti ödenir ödenmez belirli bilgilere erişimin otomatik olarak temin edilmesi gibi) işlem olarak blokzincirde bağlayıcı ve tüm sözleşme tarafları için şeffaf şekilde doğrulanabilir olması avantajına sahiptir ${ }^{32}$. Akıllı kontratlar otomatlara benzetilebilirse de teknolojinin şu an geldiği aşama göz önünde bulundurulursa belirli limitlerinin söz konusu olduğu söylenebilir. Gerçekten akıllı kontratlar, standartlaştırılmış süreçlerin yerine getirilmesi işlevine sahip olduğundan, sözleşmeye dayalı haklar ve yükümlülüklerin her türünün bu konsepte uygun düşmesi mümkün olmayabilir. Örneğin belirsiz hukuki kavramların yorumlanması bakımından akıllı kontratlarda sorun yaşanabilir. Tarafların yükümlülüklerini ihlal etmeleri ya da öngörülmesi önceden mümkün olmayan olayların gerçekleşmesi veya akıllı kontratların program kodlarında hataların ortaya çıkması durumunda da çeşitli zorluklar söz konusu olabilir. Halen var olan teknik sorunlarına rağmen akıllı kontratlar zaman ve maliyet açısından önemli avantajlar getirdiği için yıllar içinde daha da büyük anlama sahip olacaktır ${ }^{33}$.

\section{B. KRIPTO PARA KAVRAMI}

Kripto paralar, fiziksel bir varlığa sahip olmayan ${ }^{34}$, kriptografik teknolojilere dayanan ve aracılık hizmeti sunan bir kuruma gerek duyulmaksızın para transferini mümkün kılan sanal para sistemi olarak isimlendirilebilir ${ }^{35}$. Kripto paralar blokzincir teknolojisi üzerine kurulmuştur ${ }^{36}$. Blokzincir teknolojisi, kripto paraların merkeziyetsiz olarak işlem görmesini sağlamakta olup kripto paralar sayesinde ödeme işlemlerinde bir finans kuruluşunun aracılık etmesine ya da onay vermesine gerek kalmamakta ve ilgili tutar doğrudan alıcıya transfer edilebilmektedir ${ }^{37}$. Her kullanıcının sahip olduğu kripto para, bir para transferi durumunda halihazırda var olan ve merkezî olmayan şekilde

31 ibid 1093.

32 ibid 1093.

33 ibid 1093.

34 Kripto para birimlerinin öncüsü bitcoin fiziksel şekilde "casascius coin" olarak da üretilmiştir. Her bir madeni para altın, gümüş ve pirinç karışımından üretilmiş ve her birinin hologramının altında kendi bitcoin adresi ve özel anahtarı bulunmaktadır. (Bkz. Armağan Ebru Bozkurt Yüksel, 'Elektronik Para, Sanal Para, Bitcoin ve Linden Doları’na Hukuki Bir Bakış', (2015) 73 (2) İstanbul Hukuk Mecmuası, 173, 200 dipnot 158.) Ancak casascius coin olarak üretilen bu bitcoinler de aslında üzerlerinde bulundurdukları adres ve özel anahtarı temsil ettiği için yapıldığı maddeler olan gümüş, altın ve pirinç karışımının değerini değil üzerindeki adres ve özel anahtar ile ulaşlan fiziksel olmayan bitcoinin değerini temsil eder.

35 Möllenkamp and Shmatenko, (n 12) Teil 13.6, kn. 12; Murat Volkan Dülger ve Onur Özkan, 'Kripto Para Suçları: Kripto Para Birimlerinin Hukuki Boyutu ve Türk Ceza Kanunu Bakımından Değerlendirilmesi' (2020) Prof. Dr. Mehmet Emin Artuk’a Armağan 963, 966; Derya Mutluoğlu, 'Kripto Para Birimleri ve Suçtan Kaynaklanan Malvarlığı Değerlerini Aklama Suçu', (Yüksek Lisans Tezi Ankara Üniversitesi 2020) 28; Balcı (n 13) 210; Engin Tekin, 'Parada Sahtecilik Suçu', (Yüksek Lisans Tezi Hacettepe Üniversitesi 2019) 19.

36 Gunnar Groh, 'Kryptowährung' in Klaus Weber (ed), Greifelds Rechtswörterbuch (26th edn, Beck 2021) <www.beckonline.beck.de> Erişim Tarihi: 19.07.2021); Nicola Meier and Anastasia Kotovskaia, 'Finanzmarktregulatorische, währungs - und wettbewerbsrechtliche Problemstellungen', (2021) Zeitschrift für Bank - und Kapitalmarktrecht 348, 349; Möllenkamp and Shmatenko, (n 12) Teil 13.6, kn. 12; İmamoğlu (n 2) 38.

37 Möllenkamp and Guggenberger, (n 22) Teil 13.7, kn. 12; Engin (n 35) 19. 
arşivlenmiş çok taraflı işlemler dizisine eklenir ${ }^{38}$. Bu şekilde çok taraflı işlemler dizisi zincir şeklinde birbirine bağlanmak suretiyle merkezî olmayan bir kayda dönüşmektedir. Bir kişiden bir başka kişiye para transfer edilebilmesi bakımından önemli bir yenilik getiren kripto paralar, blokzincir teknolojisine dayanan merkeziyetsiz finansin önemli ürünlerinden biridir.

Kripto paraların blokzincir teknolojisi üzerinde kurulması, blokzincirin sahip olduğu "uzlaşma mekanizması" ile mümkün olmaktadır. Buna göre iki taraf arasında yapılan işlem, bir makine tarafından kayda geçirilmekte ve anında diğer makinelere haber gönderilmektedir. Bu şekilde, yapılan bütün işlemler yaklaşık 10 dakikada bir toplanıp tek bir paket haline getirilmekte; makineler bu paketin doğru olduğu konusunda uzlaşırsa, tekrar çalışmaya ve bir sonraki paketi oluşturmaya başlamaktadırlar ${ }^{39}$.

Öte yandan kripto paralar alternatif bir ödeme aracı anlamında "para birimi" ya da "para" olarak hukuki açıdan henüz tanınmamaktadır ${ }^{40}$. Fakat şu an için dünyanın çoğu noktasında finans piyasası yönetimleri, kripto paralar hakkında çeşitli düzenleyici işlemler hazırlamaktadır. Ayrıca belirtmek gerekir ki kripto paraların bazılarının sınırlı sayıda olduğu, bazılarının ise sınırsız sayıda olduğu görülmektedir. Sinırlı sayıda olan kripto paraların bu bakımdan paradan ziyade altına daha çok benzediği söylenebilir. Özellikle kripto para piyasasının başını çeken bitcoin sınırlı bir miktarda mevcuttur. Para ise daha ziyade enflasyonist bir yapıya sahip olup koşulları oluştuğu takdirde ya da ekonomik sonuçları göze alındığı takdirde sınırsız basılma özelliğine sahiptir ${ }^{41}$. Diğer yandan para kavramının sahip olduğu ödeme aracı olma özelliği her ne kadar kripto paralarda bulunuyor olsa da, bazı yönleri ile kripto paralar, para kavramı ile örtüşmemektedir ${ }^{42}$. Örneğin belirli bir otorite tarafından piyasaya sürülme özelliği ${ }^{43}$ kripto paralarda bulunmamaktadır.

\section{TOKEN KAVRAMI}

Blokzincir teknolojisi, tokenlaştırma ya da tokenizasyon adında yeni bir alana sahiptir. Bu kavram hukuki ilişkiler hakkında önemli bir yenilik getirmekte olup hakların ve alacakların belge yerine tokenlar üzerinde vücut bulması anlamına gelmektedir ${ }^{44}$. Token kavramı, birbirine bağlı karakterlerin somutlaştırılmamış bir dizisidir. Tokenlar, örneğin bir parasal değer ya da bir eşyanın mülkiyeti gibi herhangi bir bilgiyi temsil eder. Bitcoin gibi sanal para birimleri çoğu zaman para birimi tokenları (Currency Token) olarak da isimlendirilmektedir. Ancak tokenlar, hisse ya da kullanım hakları gibi birtakım başka değerleri de temsil edebilir ${ }^{45}$. Tokenlarda veri bankası girişleri söz konusu olduğu için

38 Gunnar Groh, 'Kryptowährung' in Klaus Weber (ed), Greifelds Rechtswörterbuch (26th edn, Beck 2021) <www.beckonline.beck.de> Erişim Tarihi: 19.07.2021).

Sert (n 6) 94

40 Meier and Kotovskaia (n 36) 349.

41 Bkz. ve karşılaştırınız (krşl) Sert (n 6) 95.

42 Para kavramının tanımı hakkında bkz. Serkan Merakl, 'Parada Sahtecilik Suçu (TCK m. 197)' (2020) 26(2) Marmara Üniversitesi Hukuk Fakültesi Hukuk Araştırmaları Dergisi s. 726, 732.

43 Möllenkamp and Shmatenko, (n 12) Teil 13.6, kn. 39; Balcı (n 13) 211.

44 Markus Kaulartz and Robin Matzke, 'Die Tokenisierung des Rechts', (2018) NJW 3278.

45 Nikolas Guggenberger, 'Digitale Transformation in der Industrie’ in Andreas Leupold, Andreas Wiebe ve Silke Glossner 
bir token işlemi, bir veri yığınının gönderenden alıcıya aktarılmasına yol açmayıp sadece belirli bir veri bankası girişi üzerindeki tasarruf imkanında değişikliğe yol açar ${ }^{46}$.

Bir token, özgün, benzersiz ve çoğaltılma olanağı bulunmayan bir veri bankasına girmek anlamına gelir $^{47}$. Bu veri bankası da blokzincir temeline dayanır. Token kavramı bir verinin kişiler arasında paylaşılması ya da transferi değildir. İşlem adı verilen verilerin transferi, bir veri bankası üzerindeki hakkın değiştirilmesi suretiyle olmaktadır. A ile B arasındaki bir token işlemi teknik açıdan, A’nın değil B’nin bundan sonra veri bankası üzerinde hakimiyetinin bulunduğu ve tasarrufta bulunabileceği anlamını taşır ${ }^{48}$.

Tokenlar söz konusu olduğunda iki ana gruba ayrılarak ele alınabilirler. Birincisi içsel (intristic) tokenlar olup bu tokenlar bir değer ifade ederler. İçsel tokenlar salt varlıkları itibariyle belirli bir değer atfedilebilecek tokenlardır. Dışsal (extrinsic) tokenlar ise değerlerini, bir malvarlığı değeri ile arasında olan bağlantıdan ya da tokendan türetilen bir haktan almaktadır. Dışsal tokenlar örneğin belirli bir eşya, ürün, hizmet ya da bir şirket hissesini temsil edebileceği gibi bir kıymetli evrağı da temsil edebilirr ${ }^{49}$. İçsel tokenlar para birimi tokenı ya da diğer bir deyişle ödeme aracı tokenı (Currency token) şeklinde karşımıza çıkar. Örneğin bitcoin böyledir ${ }^{50}$. Dişsal tokenlar ise hizmet tokenı (utility token) gibi bir eşya ya da hizmet üzerindeki hakkı tesis eden (buna NAGA Coin örnek verilebilir) ${ }^{51}$ ya da yatırım tokenı/ menkul kıymet tokenı (investment token/ security token) gibi sahibine klasik finans araçlarında olduğu gibi belirli bir süre sonra gelir elde etme hakkı temin eden ve klasik anlamdaki kıymetli evraklara ya da hisse senetlerine benzeyen tokenlardır ${ }^{52}$. Yatırım tokenlarına en güzel örneklerden biri aşağıda daha ayrıntılı değinilecek olan DAO Maker adını taşıyan tokendır ${ }^{53}$.

Hizmet tokenı ya da yatırım tokenları belirli bir mal üzerindeki mülkiyeti temsil ettiğinden özellikle gayrimenkul alanında yatırım tokenlarının hızla genişlemesi ve bir gayrimenkul üzerinde birden fazla kişinin mülkiyetini temsil etmesi suretiyle gayrimenkul alanında geniş bir uygulama alanı bulması muhtemeldir.

(eds), Münchener Anwaltshandbuch IT-Recht (4th edn, Beck 2021), Teil 14.2, kn. 17.

Guggenberger (n 45) Teil 14.2 kn. 17.

Ulrike Schäfer and Thomas Eckhold, 'Crowdfunding, Crowdlending, Crowdinvesting, Kryptowährungen und Initial Coin Offerings (ICOs)' in Heinz-Dieter Assmann, Rolf A. Schütze ve Petra Buck - Heeb (eds), Handbuch des Kapitalanlagerechts, (5th edn, Beck 2020), $\$ 16 a$ kn. 24, 28; Kaulartz and Matzke (n 44) 3278.

Kaulartz and Matzke (n 44) 3278.

Möllenkamp and Shmatenko, (n 12) Teil 13.6, kn. 30.

Schäfer and Eckhold, (n 47) § 16a kn. 28; Möllenkamp and Shmatenko, (n 12) Teil 13.6, kn. 31.

Kumpan (n 14) \$2 kn. $83-84$.

Schäfer and Eckhold, (n 47) §16a kn. 29 - 30; Möllenkamp and Shmatenko, (n 12) Teil 13.6, kn. 31; Kumpan (n 14) § 2 kn. 83.

Kumpan (n 14) 2 kn. 83. 


\section{MERKEZIYETSIZ FINANS KAPSAMINDA GERÇEKLEŞTIRILEBILECEK ÇEŞiTLi IŞLEM TÜRLERI}

\section{A. LiKidite MADENCILIĞi (YIELD FARMING)}

Yield Farming ya da diğer bir deyişle likidite madenciliği kavramı, merkezî olmayan borsalardaki (DEX) katılımcıların yani piyasa yapıcıların, bir piyasada likidite sağlayıp bunun karşılığında bir gelir elde ettikleri mekanizmayı ifade eder. Likidite madenciliği, merkeziyetli finans sisteminde bankaların sahip olduğu kredi verme faaliyetini ikame eder. Gerçekten likidite madenciliğinde, elinde belirli bir kripto para bulunduran kişi, elindeki bu kripto varlıktan gelir elde etmek amacıyla bunu merkeziyetsiz borsalar aracıllğı ile başkalarına borç verir. Merkeziyetsiz borsalar da kendi sistemlerinde yapılan işlemlerden elde ettikleri komisyonlardan bir kısmını bu likiditeyi sağlayan kişilere öder. Bu şekilde sisteme kripto varlık sokan kişiler, bankaların verdiği mevduat faizine benzer bir gelir elde ederken sistemden borç alan kişilere de bu sayede finansman sağlanmış olur. $\mathrm{Bu}$ da bankaların sunduğu kredi verme hizmetine benzetilebilir. Burada belirtilmesi gereken önemli hususlardan bir tanesi de merkeziyetsiz borsalar üzerinden gerçekleştirilen bu işlemler akıllı kontratlar vasitasıyla yapılabilmektedir. Dolayısıyla likidite madenciliğinin temelini akıllı kontratlar oluşturmaktadır ${ }^{54}$.

Likidite madenciliği çeşitli merkeziyetsiz borsalar üzerinden yapilabilmektedir. Bunlardan en önemlileri arasinda Compound, Synthetix, Aave, Uniswap, Balancer gibi merkeziyetsiz borsalar sayılabilir.

Likidite madenciliğinin en önemli özelliği olan ve onu merkeziyetsiz finans (Defi) aracı haline sokan husus blokzincir ve ona bağlı olarak akıllı kontratlar aracilığı ile adeta kendi kendine çalışan bir borç verme - borçlanma mekanizması sunuyor olmasıdı ${ }^{55}$. Bu yönüyle merkezi bir otorite olan bankalar denklemden çıkartılmakta ve yeni bir finans ağı kurulmuş olmaktadır.

\section{B. STAKING}

Staking işlemi yukarıda değinilen likidite madenciliğine benziyor olsa da ondan ayrılan yönleri vardır. Stakingin iki türünden bahsedilebilir: Bunlardan birincisi, stankingin "proof of stake" (hisse ispatı) adı verilen sistemin işleyebilmesi için ihtiyaç duyulan bir işlem olmasıdır. Gerçekten proof of stake sistemi, bitcoinin işletim sistemi olan proof of work (iş ispatı) sisteminin aksine ne kadar çok madencilik yapıldığından bağımsız olarak, sisteme ne kadar kripto para kilitlendiğine bağlı olarak sistem üzerinde kullanıcıya oy hakkı tanımaktadır. Blokzincir ağı üzerinde gerçekleșen bir işleme belirli oranda kullanıcı onay verdikten sonra o işlem gerçekleşebilmektedir ${ }^{56}$. İște proof of stake

54 Sert (n 6) 17. Ayrıca bkz. ve krşl. Georg Langheld and Christian Haagen, 'Decentralized Autonomous Organizations verbandsrechtliche Einordnung und Gestaltungsmöglichkeiten’ (2021) Neue Zeitschrift für Gesellschaftsrecht 724, 725.

55 Sert (n 6) 18.

56 Schäfer and Eckhold, (n 47) \$16a kn. 25; Florian Schröder, 'Protokoll zum 172. Bochumer Steuerseminar für Praktiker und Doktoranden vom 12. März 2021' (Kompetenzzentrum Steuerrecht 2021) <https://www.kompetenzzentrumsteuerrecht.de/MEDIEN/publikationen/Protokoll_172._Bochumer_Steuerseminar_final.pdf? $m=161.666 .9816 \&>$ 
sisteminde de kullanıcı, sisteme ne kadar çok kripto para kilitlerse o ölçüde oy hakkı olmakta ve buna bağlı olarak daha fazla işlem onaylayıp sistemden daha çok gelir elde edebilmektedir ${ }^{57}$. Oysa ki bitcoinin çalışma prensibi olan proof of work sisteminde kullanıcı ne kadar çok madencilik yaparsa o denli onay işlemi yapabilmektedir ${ }^{58}$. Bu da aşırı enerji tüketimini beraberinde getirmektedir.

Sisteme kripto para kilitleyip işlemlere bu kullanıcılar tarafından onay verilmesi suretiyle proof of stake sistemindeki bir işlemin gerçekleşmesi mümkün olmaktadır. Dolayısıyla staking, proof of stake sistemi üzerindeki işlemlerin onaylanabilmesi için bir gereklilik iken; likidite madenciliği ise salt gelir elde etmek amacıyla yapılan bir işlemdir.

Stakingin diğer bir türü ise "bir hizmet olarak staking" [Staking-as-a-Service (SaaS)] adı verilen türdür ${ }^{59}$. Proof of stake sürecine katılan kullanıcılar, sahip oldukları kripto paralar üzerinden pasif gelir adı verilen bir gelir de elde etmektedirler. Bu gelir, merkeziyetli finans alanındaki banka mevduat faizlerine benzetilebilir. Elinde proof of stake niteliğinde kripto para bulunduran kullanıcılar, ellerindeki bu kripto paraları, proof of stake sistemini kullanan bazı internet sitelerinin sistemlerine kilitleyerek kilitledikleri süre için bir pasif gelir elde etmektedirler. Bu yolu seçen proof of stake niteliğindeki kripto para sahipleri, proof of stake sisteminde onay verme faaliyetlerine katılmak yerine ellerindeki kripto paraları sadece faiz getiren bir varlık olarak kullanmayı tercih etmektedirler.

Öte yandan belirtmek gerekir ki staking faaliyeti, kripto paralarda deflasyon yaratmak için de faydalanılan bir yöntemdir. Gerçekten bu sayede piyasada bulunan kripto paralar kilitlenerek pasif bir konuma çekilmiş olduğundan piyasadaki işlemlere daha az konu olmaktadır. Bu sayede de ilgili kripto para türünün değerinin korunması mümkün olmaktadır.

\section{BLOKZINCIR ÜZERINDE DOĞRUDAN FON TOPLAMA (ICO= INITIAL COIN OFFERING)}

ICO kavramı blokzincir teknolojisi kullanılarak yatırımcılardan kripto para formunda bir risk sermayesi toplanması anlamını taşımaktadır ${ }^{60}$. Bu şekilde sermaye toplama faaliyeti özünde bir fon toplama faaliyeti teşkil etmektedir. Ödenen sermaye karşılığında şirket payı ya da hissesi alınması yerine ICO kapsamında firmalar bir kripto para formunda tokenlar dağıtmakta olup daha sonra yatırımcılar bu tokenları ödeme aracı ya da değer yatırımı olarak değerlendirebilmektedirler ${ }^{61}$.

59 Umut Sezer, 'Çağııızın pasif gelir elde etme yöntemi kripto para staking seçenekleri nelerdir?' (HWP, 30.07.2021), <https:// hwp.com.tr/cagimizin-pasif-gelir-elde-etme-yontemi-kripto-para-staking-secenekleri-nelerdir-189821> Erişim Tarihi: 17.08.2021.

60 Jennifer Espich, 'Potenziale der Blockchain-Technologie für die Finanzindustrie in Deutschland' (Master thesis, Hochschule Landshut 2019), 31.

61 Michaela Hönig, 'Initial Coin Offering Studie zu Kryptowährungen und der Blockchain-Technologie', (Frankfurt University of Applied Sciences 2018) <https://www.frankfurt-university.de/fileadmin/standard/Hochschule/ Fachbereich_3/Kontakt/Professor_inn_en/Hoenig/20180502_Bitcoin_Studie_fra_uas_Hoenig_V1.0.pdf> accessed 22.08.2021, 8.
} 
ICO kavramı bir yönüyle yatırım tokenı/ menkul kıymet tokenı (investment token/ security token) kavramına benzemektedir. Fakat yatırım ya da diğer bir deyişle menkul kıymet tokenları, ICO’nun aksine, sahibine klasik finans araçlarında olduğu gibi belirli bir süre sonra gelir elde etme hakkı temin eden ve klasik anlamdaki kıymetli evraklara ya da hisse senetlerine benzeyen tokenlardır. Diğer bir deyişle menkul kıymet/ yatırım tokenları, fiziksel değerler ile desteklenmekte olup bu tokenları edinen kişiler bir malvarlığı değeri ya da bir işletme kazancı sahibi olmaktadırlar. Ancak ICO kavramında sadece bir yatırım söz konusu olup bu yatırım karşıllğında yatırımcılar şirketin payını ya da kârını edinmemektedirler ${ }^{62}$.

ICO henüz hukuki olarak düzenlenmemiş bir fon toplama yöntemi olup grup finansmanı olarak da anılmaktadır. İşletme modelleri kripto paralar temelinde kurulan ve bu alanda global ya da yerel düzeyde herhangi bir düzenlemenin bulunmamasını firsat olarak gören şirketlerin sermaye toplamada başvurduğu yeni bir araçtır. Sermaye oluşturmanın yeni ve dijital bir biçimi olan bu yöntem ile firmalar borsaların katı bir şekilde düzenlenen sermaye toplama süreçlerini ya da diğer bir deyişle borsaya açılma süreçlerini (IPO= Initial Public Offering) dolanmış olmaktadırlar. Bir ICO sürecinde şirket adına yeni yaratılan bir kripto para, yatırımcıların tedavüldeki basılı paralar ya da diğer kripto paraları şirkete sermaye olarak yatırmaları karşıllğında kendilerine değiş tokuş edilmektedir ${ }^{63}$.

Öte yandan ICO konusunda henüz herhangi bir hukuksal düzenleme bulunmadığından ICO gerçekleştirmek için belirli bir şirketin kurulmuş olması gerekmemektedir. Dolayısıyla gerçek kişiler de sermaye toplamak amacıyla teknik olarak token ihraç edebilir veya diğer bir deyişle topluluklara bunu sunabilir ${ }^{64}$.

\section{BLOKZINCIR ÜZERINDE VARLIK TOKENLAȘTIRMA}

Blokzincir üzerinde varlık tokenlaştırma da merkeziyetsiz finans kapsamında gerçekleştirilebilecek işlem türlerinden bir diğeridir. Bu kapsamda yukarıda açıklandığı üzere ${ }^{65}$ hizmet tokenı (utility token) gibi bir eşya ya da hizmet üzerindeki hakkı tesis eden (buna NAGA Coin örnek verilebilir) ${ }^{66}$ ya da yatırım tokenı/ menkul kıymet tokenı (investment token/ security token) gibi sahibine klasik finans araçlarında olduğu gibi belirli bir süre sonra gelir elde etme hakkı temin eden ve klasik anlamdaki kıymetli evraklara ya da hisse senetlerine benzeyen tokenlar söz konusu olmaktadır ${ }^{67}$. Bu şekilde özellikle bir eşya üzerinde birden fazla kişi arasında mülkiyet tesis edilebilmekte olup diğer bir deyişle bir malvarlığı değeri blokzincir üzerinde tokenlaştırılmak suretiyle paylara bölünebilmektedir. $\mathrm{Bu}$

62 Espich (n 60) 102.

63 Hönig (n 61) 7; Patrick Schueffel, 'The Concise Fintech Compendium', (Fintech Vitalizing Banking 2017) <http://schueffel. biz/wp-content/uploads/2017/09/Schueffel-2017-The-Concise-FINTECH-COMPENDIUM.pdf> accessed 23.08.2021, 15.

64 Hönig (n 61) 7.

65 Bkz. I C 2 c altında yapılan açıklamalar.

66 Kumpan (n 14) \$2 kn. $83-84$.

67 Schäfer and Eckhold, (n 47) \$16a kn. 29 - 30; Möllenkamp and Shmatenko, (n 12) Teil 13.6, kn. 31; Kumpan (n 14) § 2 kn. 83 . 
yolla ilerleyen yıllarda taşınmazlar üzerindeki mülkiyetin de blokzincir üzerinde tokenlaştırılması suretiyle mülkiyetin çeşitli kişiler arasında bölüştürülmesi gündeme gelebilecektir. Blokzincir üzerinde varlık tokenlaştırılması suretiyle merkeziyetsiz bir düzen içerisinde malvarlı̆̆ı değerlerinin mülkiyeti tesis edilebilmekte ve güvenli bir şekilde el değiştirebilmektedir ${ }^{68}$.

\section{E. BLOCKCHAIN KULLANARAK BORÇ VERME}

Burada konunun daha iyi izahı bakımından bunlardan belki de en önemlilerinden biri olan MakerDAO akıllı kontratı hakkında bilgi vermekte fayda vardır. MakerDAO akıllı kontratının MKR isimli bir kripto para birimi bulunmaktadır. Bu kripto para birimine sahip olan kullanıcılar bu akıllı kontrat üzerinde oy hakkına sahip olmaktadır. Ayrıca bu akıllı kontratın DAI isimli bir sabit kripto para birimi de bulunmaktadır. Kullanıcılar, MakerDAO isimli akıllı kontrat üzerinden ellerinde bulunan kripto paraları teminat olarak göstermek suretiyle sistemin kripto para birimi olan ve her zaman 1 Amerikan Dolarına eşit ya da yakın olan sabit bir kripto para birimi niteliğindeki DAI üretebilmektedirler. Kullanıcılar sisteme teminat olarak koydukları 150 birim kripto paralarına karşılık (ki bu MakerDAO’da Ethereum olabilir; çünkü MakerDAO Erc-20 ağı üzerine kuruludur.) 100 birim DAI elde etmektedirler. Daha sonra bu DAI'leri kripto para borsalarında Amerikan Dolarına çevrilip harcayabilmektedirler. Daha sonra sisteme teminat olarak yatırılan kripto para (Ethereum) sistemden geri çekilmek istendiğinde kripto para borsaları üzerinden DAI satın alınmakta ve tekrar MakerDAO üzerinden bu DAI'ler sisteme sokularak kullanıcılar teminatlarına kavuşabilmektedirler ${ }^{69}$. Dolayısıyla sisteme adeta Ethereumlar teminat gösterilmek ya da diğer bir deyişle ipotek edilmek suretiyle sistemden 150 birim Ethereum karşıllı̆ında 100 birim DAI kredi olarak kullanılmaktadır. Bu işlem için sisteme kullanıcı tarafından belirli bir yüzde oranında ödeme yapılmaktadır. Bu ödemeye istikrar komisyonu denmektedir. Bunun özü sisteme, kredi olarak alınan DAI için bir faizin ödeniyor olmasıdır. Sistemden ne kadar çok DAI çekilirse piyasada o kadar çok DAI olacağından DAI'nin değeri bu durumda 1 Amerikan Dolarının altına düşecektir. DAI’nin değerinin 1 Amerikan Dolarına yaklaştırılması için kullanıcıların ortak kararı ile sistemden çekilen DAI için ödenecek faizin oranı artırılır. Sistemden DAI borç almanın maliyeti böylece artacağ 1 için DAI talebi azalacak ve DAI’nin değeri artıp yeniden 1 Amerikan Dolarına yaklaşacaktır. $\mathrm{Bu}$ nedenle klasik merkeziyetli finansta bankadan çekilen kredi faiz oranına benzetilebilecek istikrar komisyonu oranının miktarı DAI’nin değerinin 1 Amerikan Dolarına yaklaşıp uzaklaşmasına göre belirlenmektedir ${ }^{70}$.

$\mathrm{Bu}$ sistemin avantajlı yanı, merkeziyetli finans aracı olarak bankalardan alınan kredilerin aksine, kullanıcıların bürokrasi ile ya da kredi notu ile uğraşmamalarıdır. Ayrıca sisteme yatırılan 150 birim teminat karşıllı̆̆ sistemden 100 birim DAI alınabilmesinin sebebi de, kripto paralardaki

68 Bu hususta ayrica bkz. Kaulartz and Matzke (n 44) 3280.

69 Sert (n 6) 18 .

70 Bu hususta bkz. Maker Team, 'Das DAI Stablecoin System-Whitepaper' <https://makerdao.com/whitepaper/DaiWhitepaper-Dec17-de.pdf> Erişim Tarihi: 22.07.2021; Ayrıca bkz. https://coingenius.news/tr/makerdao-slashesstability-fees-as-stablecoin-demand-wanes/, erişim tarihi: 22.07.2021. 
aşırı dalgalanmalardır. Gerçekten sisteme teminat olarak yatırdığınız ve üzerinden gelir elde etmek istediğiniz 150 birim Ethereum bir anda aşırı değer kaybedebilir. Bu nedenle sisteme yatırılan paranın daha altında bir tutarın kullanıcılara DAI olarak verilmesi esası benimsenmektedir. Ethereum aşırı değer kaybettiğinde teminat olarak yatırdığınız Ethereum sistem tarafından otomatik olarak bozdurulmaktadır.

Burada önemle vurgulanması gereken bir husus da şudur ki, merkeziyetsiz finans (Defi) aracı olan bu tür merkeziyetsiz borsaların tek elden yönetildiğini söylemek pek mümkün değildir. Gerçekten bu merkeziyetsiz finans araçları örneğin MakerDAO’nun temelinde yer alan Maker Protokolü, Maker Vakfı tarafından geliştirilmiştir. Fakat bu ağ üzerinde yapılan işlemler katılımcıların onayı ile ortaya çımaktadır. Bu nedenle merkeziyetsiz finans araçlarının sahibinin bulunduğunu söyleyebilmek ya da tek bir merkezden yönetildiğini söylemek merkeziyetli finans araçlarına göre çok zordur. MakerDAO platformunun temelini oluşturan Maker Protokolü, Maker (MKR) bulunduranlar tarafından yönetilmektedir. Bu ağda elinde en çok Maker (MKR) bulunduran kişilerin en çok oy hakkı bulunmakta olup yapılan işlemlere verilen onaylar bu oy haklarına göre belirlenmektedir.

\section{TÜRK HUKUKUNDA MERKEZIYETSIZ FINANS FAALIYETLERININ TABi OLDUĞU HUKUKI DÜZENLEMELER}

Türk hukukunda merkeziyetsiz finans faaliyetleri hakkında şu an için düzenleyici bir işlem bulunmamaktadır. Bu konuda sadece Türkiye Cumhuriyet Merkez Bankası tarafından çıkartılan ve 16.04.2021 gün ve 31456 sayılı Resmi Gazetede yayımlanarak yürürlüğe giren Ödemelerde Kripto Varlıkların Kullanılmamasına Dair Yönetmelik’te sinırlı bir düzenleme bulunmaktadır. Bu Yönetmelik m. 3 ve 4 ’te şu hükümler getirilmiştir:

\section{“Ödemelerde kripto varlıkların kullanılmaması}

MADDE 3 - (1) Bu Yönetmeliğin uygulanmasinda kripto varlik, dağttık defter teknolojisi veya benzer bir teknoloji kullanılarak sanal olarak oluşturulup dijital ağlar üzerinden dağtıım yapılan, ancak itibari para, kaydi para, elektronik para, ödeme aracı, menkul kıymet veya diğer sermaye piyasası aracı olarak nitelendirilmeyen gayri maddi varlklar ifade eder.

(2) Kripto varlıklar, ödemelerde doğrudan veya dolayl şekilde kullanılamaz.

(3) Kripto varlkların ödemelerde doğrudan veya dolayl șekilde kullanılmasına yönelik hizmet sunulamaz.

Ödeme hizmetlerinin sunulmasında ve elektronik para ihracında kripto varlıkların kullanılmaması

MADDE 4 - (1) Ödeme hizmeti sağlayıcıları, ödeme hizmetlerinin sunulmasında ve elektronik para ihracında kripto varlıkların doğrudan veya dolayl olarak kullanılacağı bir şekilde iş modelleri geliștiremez, bu tür iş modellerine ilişkin herhangi bir hizmet sunamaz. 
(2) Ödeme ve elektronik para kuruluşları, kripto varlıklara ilişkin alım satım, saklama, transfer veya ihraç hizmeti sunan platformlara veya bu platformlardan yapılacak fon aktarımlarına aracılık edemez."

Görüldüğ̈ü üzere kripto varlıkların tanımı yapılmış ve bu kripto varlıkların sadece ödemelerde kullanılamayacağı düzenlenmiştir. Buradan hareketle ödeme aracı olarak kullanılmadı̆̆ sürece kripto varlıkların oluşturulması, işletilmesi ve kullanılması şu an için hukukumuzda serbesttir ${ }^{71}$. Ancak bu konuda T.C. Hazine ve Maliye Bakanlığı’nın yeni bir düzenleyici işlem yapma hazırlığı içinde olduğu bilinmektedir.

Öte yandan bu konuda eleştirilmesi gereken hususlardan biri merkeziyetsiz finans alanında yapılacak düzenleyici işlemin yönetmelik düzeyinde kalmasıdır. Finans alanında yapılan ve çok yaygın etkileri olacak bir düzenleyici işlemin muhakkak kanun seviyesinde olması gerekir. Özellikle bu alanda merkeziyetsiz finans araçları hakkında yapılan düzenlemelerin kişilerin mülkiyet haklarını sınırlandırdığı göz önünde tutulduğu takdirde Anayasa m. 35/ 2 gereği bu konudaki bir sınırlandırmanın sadece kanunla yapılması gerekir. Nitekim bu konuda merkeziyetli finans alanında yapılan düzenlemelerin ve kısıtlamaların kanunla yapılıyor olması, aynı güvenceden merkeziyetsiz finans araçlarının da faydalanması gerektiği yönündeki görüşümüzü destekler niteliktedir. Örneğin merkeziyetli finans alanında en önemli düzenlemelerden olan 5411 sayılı Bankacılık Kanunu, 6361 sayılı Finansal Kiralama, Faktoring, Finansman ve Tasarruf Finansman Şirketleri Kanunu, 6493 sayılı Ödeme ve Menkul Kıymet Mutabakat Sistemleri, Ödeme Hizmetleri ve Elektronik Para Kuruluşları Hakkında Kanun'un bu şekilde olduğu görülmektedir. Bu bakımdan kanımızca merkeziyetsiz finansın da tıpkı merkeziyetli finans araçlarının tabi olduğu esas ve usullere benzer şekilde düzenlenmesi bir zorunluluktur.

\section{MERKEZIYETSIZ FINANS FAALIYETLERININ IZINSIZ BANKACILIK FAALIYETINDE BULUNMA SUÇU BAKIMINDAN DEĞERLENDIRILMESi}

\section{A. GENEL OLARAK}

5411 sayılı Bankacılık Kanunu m. 150/1'de izinsiz bankacılık faaliyetinde bulunma eylemi suç olarak düzenlenmiştir. Buna göre;

"Madde 150 - Bu Kanuna göre alınması gereken izinleri almaksızın banka gibi faaliyet gösteren ya da mevduat kabul eden yahut katılım fonu toplayan gerçek kişiler ile tüzel kişilerin görevlileri, üç yıldan beş yıla kadar hapis ve beşbin güne kadar adlî para cezası ile cezalandırılır. Ayrıca, bu suçun bir işyeri bünyesinde işlenmesi hâlinde bu işyerlerinin bir aydan bir yıla kadar, tekerrür hâlinde ise sürekli olarak kapatılmasına karar verilebilir."

Bankacılık Kanunu m. 150/1'de suç sayılan eylemler, "Banka gibi faaliyet gösterme”, "mevduat kabul etme" ya da "katılım fonu toplama" faaliyetleridir. Bu bakımdan merkeziyetsiz finans faaliyetlerinin bu eylemlerin kapsamında kalıp kalmadığı incelenmelidir.

71 Bkz. ve krşl. İmamoğlu (n 2) 118 - 119. 


\section{B. SUÇLA KORUNAN HUKUKI DEĞER}

İzinsiz bankacılık faaliyetinde bulunma suçuyla korunan hukuki değer bankacılık düzenidir ${ }^{72}$. Bu hukuki değer toplumun genelinin sahip olduğu bir nitelik taşımakta olup ekonomik hayatın sağlıklı bir şekilde işlemesi bu suç tipi ile güvence altına alınmak istenmiştir. Ekonomi düzenini koruyacak bu tür bir suç tipi bulunmadığı takdirde banka ve finans sektörünün sahip olduğu ayrıcalıklar ve işlev ortadan kalkacaktır. Gerçekten bu tür bir suç tipine yer verilmesi suretiyle yasadışı yapılanmaların ortaya çıkması ve ekonomik düzenin temelini sarsacak türden bankacılık benzeri paralel bir düzenin oluşmasının önüne geçilmesi amaçlanmaktadır. Diğer taraftan toplumun bankacılık ve finans düzenine ve bu düzenin kurumlarına duyduğu güvenin de bu suç ile korunmakta olduğu söylenebilir ${ }^{73}$. Son olarak bu suç tipi ile kişilerin mülkiyet haklarının korunduğu da savunulmaktadır ${ }^{74}$.

\section{BANKA GIBI FAALIYET GÖSTERME \\ I. GENEL OLARAK}

Merkeziyetsiz finans araçları ile gerçekleştirilen işlemlerin izinsiz bankacılık faaliyetinde bulunma suçuna yol açıp açmayacağı incelenirken bankacılık faaliyetlerinin neler olduğu konusunda 5411 sayılı Bankacılık Kanunu m. 4’teki sınırlayıcı şekilde ${ }^{75}$ yapılan sayımdan faydalanılabilir. Bu sayımda merkeziyetsiz finans araçları bakımından özellik ve benzerlik gösteren kısım şu şekildedir: “Bankalar, diğer kanunlarda öngörülen hükümler saklı kalmak kaydıyla aşağıda belirtilen faaliyetleri gerçekleştirebilirler:

\section{a) Mevduat kabulï.}

\section{b) Katılım fonu kabulï.}

\section{c) Nakdî, gayrinakdî her cins ve surette kredi verme işlemleri...”}

Merkeziyetsiz finans araçlarına benzerliği bakımından ele alınabilecek üç faaliyet alanı mevduat kabulü, katılım fonu kabulü ve kredi verme faaliyetidir. Mevduat kabul etme ve yatırım fonu kabul etme faaliyetlerine aşağıda ayrıca yer verilecektir. Bu nedenle bu başlık altında sadece kredi verme faaliyeti ele alınacaktır.

72 Hakan Karakehya, 'İzinsiz Bankacılık Faaliyetinde Bulunma Suçu' (2008) LXVI (1) İ̈UHH 63, 72; Selman Dursun, Bankacılık Düzenine Karşı İşlenen Suçlar, (Seçkin 2006) 196.

73 Hamide Zafer, 'Tefecilik Suçu (TCK m. 241)' (2018) 4(2) Beykent Üniversitesi Hukuk Fakültesi Dergisi 69, 77; Asuman Aytekin İnceoğlu, ‘Bankacılık Kanunu’nda Yer Alan Suçlar' (Doktora Tezi, Marmara Üniversitesi 2006) 146; Davut Gürses, ‘'̇zinsiz Faaliyette Bulunmak Suçu’ (2012) 23(80) Bankacılar Dergisi 29, 32; Çağatay Çınar, ‘6362 Sayılı Sermaye Piyasası Kanunu’ndaki Usulsüz Halka Arz ve İzinsiz Faaliyette Bulunma Suçları' (Yüksek Lisans Tezi, İstanbul Üniversitesi 2019) 141.

74 Gürses (n 73) 32; Çınar (n 73) 141.

75 Aysel Gündoğdu, Bankacılık Hukuku, (6. Baskı, Seçkin 2019) 29; Aliye Akgün, Mevduat Sözleşmeleri (Seçkin 2020) 19. Aksi yönde bkz. İnceoğlu (n 73) 127. 
Kredi verme faaliyeti, belirli bir faiz oranı karşılığında bankaların müşterilerine borç ya da avans vermesidir $^{76}$. Bu faaliyet merkeziyetli finans sisteminin en önemli araçlarından olup bu sistemin en önemli aktörlerinin başında gelen bankaların varoluş sebeplerinden bir tanesidir. Merkeziyetsiz finans araçları da esasen merkeziyetli finans araçlarına bir alternatif oluşturma amacıyla ortaya çıktığından aralarında çeşitli benzerlikler bulunmaktadır. Bu benzerliklerden hareketle yukarıda saydığımız çeşitli merkeziyetsiz finans araçlarının kredi verme faaliyeti olarak nitelendirilmesi mümkün olur ise bu durumda Bankacılık Kanunu m. 150'deki izinsiz bankacılık faaliyetinde bulunma suçu oluşabilir.

Kredi verme eylemine benzerlik taşıyan merkeziyetsiz finans aracı, blokzincir teknolojisi kullanılarak borç verilmesidir. Yukarıda bu başıı altında özellikle MakerDAO akıllı kontratı örnek verilmişti ${ }^{77}$. Blokzincir kullanılarak borç verme faaliyeti, adından ötürü kredi verme faaliyeti ile aynı anlamı taşıyor gibi algılanabilir. Ancak blokzincir kullanılarak borç verme faaliyetinin, bankaların verdiği kredilerden oldukça farklı yönleri bulunmaktadır. Kısaca bu farklılıklara ve bunun yanısıra benzerliklere değinmekte fayda vardır.

Her iki faaliyet arasındaki benzerlikler,

- Belirli bir miktarda paraya ihtiyacı bulunan kişilerin bu ihtiyaçlarının karşılanması.

- İhtiyacını kredi kullanarak ya da blokzincir teknolojisi üzerinden aldığı tutarla karşılayan kişinin bu tutarı iade etme yükümlülüğünün bulunması.

- Bu iade işlemi sırasında kullandığı kredi ya da borcun üzerinde bir tutarın iade edilmesinin gerekmesi.

- Kredi kullanan kişi faiz öderken; blokzincir teknolojisi ile borç alan kişi istikrar komisyonu ödemektedir.

İki faaliyet arasındaki farklılıklar ise,

- Bankadan kredi kullanan kişinin bu tutarı banka adı verilen fiziken belirlenebilen bir kurumdan alması söz konusu iken, blokzincir teknolojisi üzerinden borç alan kişinin bu tutarı kimden aldı̆̆ı net olarak tespit edilememektedir.

- Kredi kullanan kişinin ne kadar faiz ödeyeceği krediyi kullandığı an belli ve sabit iken blokzincir teknolojisi üzerinden borç alan kişinin ödeyeceği istikrar komisyonu oranı sürekli şekilde değişebilmekte olup sabit değildir.

- Kredi kullanmak için her zaman bir ipotek işlemi yapmak gerekmese de, blokzincir üzerinden borç alınırken örneğin MakerDAO’da sisteme 100 birim borç karşılığında muhakkak 150 birim kilitlenmelidir.

76 Gündoğdu (n 75) 34; Akgün (n 75) 20.

77 Bkz. yukarıda II E başlı̆̆ı altında yapılan açıklamalar. 
- Bankadan kredi kullanan kişi bu tutarı para ya da gayri nakdi şekilde alabilirken blokzincir üzerinden borç alan kişi kripto para ile bu tutarı elde etmekte; daha sonra bu şekilde elde ettiği kripto parayı, arzu ederse kripto para borsalarına sokarak dolar ya da diğer para birimlerine çevirmek suretiyle harcayabilmektedir.

- Kredi kullanan kişinin kullandığı krediden elde edilen kar bankanın mülkiyetine geçmekte iken, blokzincir teknolojisi üzerinden elde edilen kar sisteme kalmakta ve sistemin paydaşları arasında oy hakları doğrultusunda dağıtılmaktadır. Dolayısıyla blokzincir teknolojisi üzerinden borç alma faaliyeti sonucu elde edilen karın kime kaldığının tespiti oldukça zorlaşmaktadır. Çünkü bu faaliyete binlerce, onbinlerce paydaş katılabilmektedir.

- Bununla bağlantılı olarak kredi verme süreci banka tarafından yürütülmekte iken blokzincir üzerinden borç verme eylemi pek çok kişinin bir araya gelmesi ve bu işleme onay vermesi ile gerçekleşmektedir.

İki faaliyet arasında bu denli farklılıkların bulunması, merkeziyetsiz finansın, merkeziyetli finansın özelliklerine karşı geliştirilmiş bir sistem olmasından kaynaklanmaktadır. Gerçekten de merkeziyetsiz finans, merkeziyetli finanstaki tekelleşme ve bu tekelleşmenin bankalar ya da kredi kuruluşları tarafından kötüye kullanılmasına karşı bir alternatif yol olarak ortaya çıkmıştır.

$\mathrm{Bu}$ açıklamaların ardından blokzincir kullanılarak borç verme faaliyetinin Bankacılık Kanunu m. 150'deki "banka gibi faaliyet gösterme" eylemine uyup uymadığ 1 incelenmelidir. İlk bakışta suç tipinde yer verilen "banka gibi faaliyet gösterme" ibaresinin belirlilik ilkesine uygun düşmediği düşünülebilir. Belirlilik ilkesine göre suç tipinde yer verilen eylemlerin hiçbir şüpheye yer burakmayacak surette net ve anlaşılır olması gerekmektedir ${ }^{78}$. Ancak kanunkoyucu banka gibi faaliyet gösterme eylemine yer verirken Bankacılık Kanunu m. 4'te sınırlı şekilde saydığ faaliyetleri kastetmiş̧tir ${ }^{79}$. Dolayısıyla Bankacılık Kanunu m. 4’te bankacılık faaliyetleri açık ve net olarak sayıldığı için bu düzenleme belirlilik ilkesini ihlal etmemektedir. Buna karşılık Bankacılık Kanunu m. 4’teki faaliyetlerin bir defaya mahsus izinsiz olarak yapılmasının yeterli olup olmadığı; bu faaliyetlerin düzenli olarak izinsiz şekilde gerçekleşmesinin gerekip gerekmediği ise tartışmalıdır ${ }^{80}$. Bu konuda kanımızca suçun oluşması için Bankacılık Kanunu m. 150 uyarınca banka gibi faaliyet göstermenin fail tarafından hiçbir şüpheye yer bırakmayacak ölçüde dış dünyaya yansıtılmış olması gerekir. Bu noktada bu davranışların bir defalık icra edilmesi ile failin bu yönde bir iradesinin bulunduğunu dış dünyaya yansıtmış olduğunun kabul edilmesi mümkün olmayacaktır ${ }^{81}$. Dolayısıyla maddi unsur ile manevi unsur bir arada ele alınarak bir sonuca ulaşılmalıdır.

78 Timur Demirbaş, Ceza Hukuku Genel Hükümler, (15. Baskı, Seçkin 2020) 123; Mehmet Emin Artuk, Ahmet Gökcen, Mehmet Emin Alşahin ve Kerim Çakır, Ceza Hukuku Genel Hükümler, (14. Baskı, Adalet 2020) 51; İzzet Özgenç, Türk Ceza Hukuku Genel Hükümler, (16. Baskı, Seçkin 2020) 132; Veli Özer Özbek, Koray Doğan ve Pınar Bacaksız, Türk Ceza Hukuku Genel Hükümler, (11. Baskı, Seçkin 2020) 70; Mahmut Koca ve İlhan Üzülmez, Türk Ceza Hukuku Genel Hükümler, (13. Baskı, Seçkin 2020) 58; Berrin Akbulut, Ceza Hukuku Genel Hükümler, (6. Baskı, Adalet 2019) 107.

79 Çiğdem Güven, 'Bankacılık Faaliyetine İlișkin Ceza Sorumluluğu', (Doktora Tezi, Ankara Üniversitesi 2016) 157 vd.

80 Dursun (n 72) 202; Güven (n 79) 157.

81 Gürses (n 73) 36. 
Blokzincir üzerinden borç verme faaliyetinin "banka gibi faaliyet gösterme" olarak nitelenebilmesi için;

- Blokzincir üzerinden borç verme eylemini işleyen failin belirlenebilir olması,

- Bu eylemin objektif olarak Bankacılık Kanunu m. 150'de ifade edilen "banka gibi faaliyet gösterme” eyleminin kapsamında kalıyor olması; diğer bir deyişle suçun maddi unsurunu gerçekleştirmesi;

- Bu eylemin gerçekleşmesini sağlayan sürece katılan her bir kişinin, yaptığı bu faaliyetin yani onay verdiği borç verme işleminin "banka gibi faaliyet gösterme" eylemini oluşturduğunun bilincinde olması; diğer bir deyişle kasten hareket etmiş olması;

Bu eylemin cezalandırılabilmesi için;

- Bu eylemi gerçekleştiren her bir kişinin bu faaliyetin haksızlık teşkil ettiği hususunda bir bilince sahip olması; diğer bir deyişle haksızlık bilincinin bulunması gerekmektedir.

\section{MADDI UNSUR BAKIMINDAN}

\section{A. FAIL}

Maddi unsur bakımından tartışılması gereken ilk husus fail kavramıdır. Blokzincir üzerinden borç verme eyleminin gerçekleşmesini sağlayan kişiler öncelikle ele alınmalıdır. Bu nedenle bu suçun oluşması bakımından, merkeziyetsiz finans alanında çeşitli şekillerde faaliyet gösteren kripto para kullanıcılarının, madencilerin, kripto para borsalarının, merkeziyetsiz borsaların, cüzdan sağlayıcıların ya da kripto paraları ilk olarak üreten ve ortaya çıkan kaşif adı verilen kişilerin fail olma imkanları bulunmamaktadır ${ }^{82}$. Çünkü bu süjeler blokzincir üzerinden borç verme faaliyetine katılmamaktadır. Burada bu işlemlere onay verme faaliyetini gerçekleştiren kişilere yoğunlaşmak gerekmektedir. Staking faaliyeti bakımından ise aşağıda mevduat kabul etme eylemi altında fail unsuru hakkında yapılan açıklamalara bakılmalıdır.

Merkeziyetsiz finansta işlemler, merkezi bir kurum tarafından gerçekleştirilmediği için, örneğin MakerDAO akıllı kontratı üzerinde gerçekleştirilen işlemlere onay vererek bu sistemin işlemesini sağlayan kişilerin her birinin fail olarak kabul edilmesi gerekir. Ancak bu durumda da en ufak bir işlem için dahi binlerce ve belki de onbinlerce kişinin tespit edilmesi gerekecektir. Bu ise neredeyse imkansız bir durumdur.

Ayrıca MakerDAO akıllı kontratını hazırlayan yazılımcıların ise burada fail olarak kabul edilebilmeleri mümkün değildir. Çünkü bu yazılımcılar MakerDAO isimli akıllı kontratın yazılımını yapmış olup akabinde sistemin işleyişine ve her bir onay verme işlemine müdahil olamamaktadırlar. Bu sistem merkeziyetsiz şekilde sadece kullanıcıların onayı ile çalışmaktadır.

82 Merkeziyetsiz finans araçlarının süjeleri için bkz. Balcı (n 13) 216 vd. 


\section{B. MAĞDUR}

$\mathrm{Bu}$ suçun mağduru toplumdur. Suçun koruduğu hukuki değer göz önünde tutulmak suretiyle mağdur belirlenmektedir ${ }^{83}$. İzinsiz bankacılık faaliyeti eylemleri söz konusu olduğunda da mağdur toplumu oluşturan herkes olmaktadır. Bu açıdan bu eylemlerin muhatapları suçtan zarar gören olarak nitelendirilebilir. Fakat kanımızca blokzincir üzerinden borç verme faaliyetine katılan kişilerin bu suçtan zarar gören olarak kabul edilmeleri mümkün değildir. Çünkü bu kişiler bu faaliyete kendi özgür iradeleri ile katılmakta olup bu faaliyete katıldıkları için herhangi bir olumsuz netice ile de karşılaşmamaktadırlar. Aksine bu faaliyet aracılığı ile malvarlıklarını artırma fırsatı bulmaktadırlar. $\mathrm{Bu}$ açıdan izinsiz bankacılık faaliyetinde bulunma suçunun tefecilik suçu ile benzerlik taşımasından ötürü mağdur unsuru açısından bir kıyaslama yapıldığı takdirde her iki suçun mağdurunun da toplum olduğu söylenebilir. Ancak tefecilik suçunda borç para alan kimsenin suçtan zarar gören olarak kabulü mümkün olmasına rağmen ${ }^{84}$ izinsiz bankacılık faaliyeti suçu bakımından blokzincir üzerinden borç verme faaliyetine katılan tarafların suçtan zarar gören olarak kabul edilmeleri mümkün değildir. Çünkü tefecilik suçunda borç alan kimse çoğu zaman piyasanın oldukça üstünde bir faiz oranı ile borçlanmakta iken blokzincir üzerinden borç verme faaliyeti genellikle bu şekilde ölçüsüz bir fark içermemektedir.

\section{EYLEM}

\section{AA. BANKA GIBI FAALIYET GÖSTERME EYLEMI}

Blokzincir üzerinden borç verme faaliyetinin, "banka gibi faaliyet gösterme” eyleminin kapsamında olduğunun söylenebilmesi için objektif olarak bankacılık faaliyetlerinden birini oluşturması gerekir. Blokzincir üzerinde borç verme faaliyeti maddi anlamda esasen bankanın verdiği krediden çok farklı değildir. Çünkü belirli bir tutara ihtiyaç duyan biri bankaya değil blokzincir sisteminde kurulu bir akıllı kontrata başvurarak bu akıllı kontratın kurallarına uymak suretiyle istediği tutardaki kripto paraya ulaşabilmektedir. Ayrıca kredi verme faaliyetinin özünde yer alan verilen krediden ya da borçtan fazlasının geri alınması kuralı blokzincir üzerinde gerçekleştirilen borç verme işlemleri bakımından da geçerliliğini korumaktadır. Yukarıda da belirtildiği üzere blokzincir üzerinden borç alındığında faiz yerine istikrar komisyonu adı verilen bir tutar sisteme ödenmektedir. Bu noktada faiz yerine istikrar komisyonu adı verilmesi, faaliyetin özünü etkilememektedir. Tüm bu açılamalardan hareketle aslında blokzincir üzerinden borç verme işleminin, kredi verme faaliyetinden başka bir şey olmadı̆̆ı söylenebilir. Bu yorumun temelinde bu faaliyetin sadece banka ve kredi kuruluşlarına özgü olması da yatmaktadır. Ancak izinsiz bankacılık faaliyetinde bulunma suçunun oluşması için, blokzincir üzerinden borç verme faaliyetinin, salt objektif olarak "banka gibi faaliyet gösterme" eylemine uyması yeterli değildir. Ayrıca aşağıdaki unsurların da gerçekleşmesi gerekmektedir.

83 Özgenç (n 78) 175; Zafer (n 73) 79; Özbek, Doğan ve Bacaksız (n 78) 213. Ayrıca bkz. Artuk, Gökcen, Alşahin ve Çakır (n 78) 372; Koca ve Üzülmez (n 78) 114 - 115; Akbulut (n 78) 383.

84 Zafer (n 73) 81. Borç alan kişinin tefecilik suçunun mağduru olduğu görüşü için bkz. Özbek, Doğan ve Bacaksız (n 83) $947-948$. 
Öte yandan bankadan alınan her kredi için ipotek işlemi yapılmadığı; ancak örneğin MakerDAO üzerinden borç alınmak istendiği takdirde borç alınacak her 100 birim tutar için sisteme mutlaka en az 150 birim tutarın kilitlenmesi gerektiği ve bunun da bankaların verdiği kredi ile birebir örtüşmediği söylenebilirse de kanımızca bankalar her kredi işleminde ipotek işlemi yapmasalar dahi mutlaka kredi kullanıcısının malvarlığına ve kredisini ödeme gücünün bulunup bulunmadığını gösteren kredi notuna baktığ için aslında her iki faaliyet bu noktada da kesişmektedir.

\section{BB. TEFECILIK EYLEMINDEN FARKI}

Tefecilik suçu TCK m. 241'de topluma karşı suçlar kısmında düzenlenmiş olup "kazanç elde etmek amacıyla başkasına ödünç para vermek” şeklinde tanımlanmıştır. Tefecilik suçunun kanundaki tanımı oldukça geniş bir kapsama sahip olup özellikle aşırı faydalanma ya da gabin unsuruna suç tipinde yer verilmemesinin büyük bir eksiklik olduğu öğretide ileri sürülmektedir ${ }^{85}$.

Blokzincir üzerinden borç verme faaliyeti, izinsiz bankacıllk faaliyetinde bulunma eylemi bakımından değerlendirilirken bu eylemin tefecilik suç tipine uyup uymadığı hususuna da değinmekte fayda bulunmaktadır. Bu sayede tefecilik ve izinsiz bankacılık faaliyetinde bulunma suçları arasındaki farklılık da ortaya konulabilir. Tefecilik suçunda kazanç elde etmek amacıyla başkasına ödünç para vermek eylemi söz konusu olup bu ödünç para verme eyleminin bir meslek haline getirilmesi durumunda artık tefecilik suçunun değil izinsiz bankacılık faaliyetinde bulunma suçunun oluşacağı söylenmelidir. Bu iki suç arasında özel-genel norm ilişkisi bulunmayıp ${ }^{86}$ eylemin ilk defa gerçekleştirildiği durumlarda ya da düzenli olarak gerçekleştirilmediği durumlarda tefecilik suçu; eylemin düzenli bir faaliyet şeklinde adeta bir meslek olarak gerçekleştirildiği durumlarda borç verilen tutarların boyutu da göz önünde tutularak izinsiz bankacılık faaliyetinde bulunma suçu oluşacaktır ${ }^{87}$.

Her iki suç tipi incelendiğinde, blokzincir üzerinden borç verme faaliyetine katılan kullanıcıların bu faaliyeti düzenli gerçekleştirip gerçekleştirmedikleri ve yaptıkları işlemlerin maddi açıdan değeri esas alınarak bir sonuca ulaşılmalıdır. Fakat bu faaliyetin kullanıcılar tarafından düzenli ve sürekli olarak gerçekleştirildiği söylenebilirse de blokzincir üzerinden borç verilecek tutarların oldukça düşük bir tutar teşkil etmesi söz konusu olabilir. Bu unsurlar değerlendirilerek her somut olay özelinde eylemin kimi zaman tefecilik kimi zaman izinsiz bankacilık suçunun tanımına uyması mümkün olabilir ${ }^{88}$.

85 Veli Özer Özbek, Koray Doğan ve Pınar Bacaksız, Türk Ceza Hukuku Özel Hükümler, (15. Baskı, Seçkin 2020) 944; Veli Özer Özbek, 'Tefecilik Suçu' (2010) 14 Ceza Hukuku Dergisi 29, 36 - 37; Zafer (n 73) 76. Ayrıca bkz. Zekiye Özen İnci, Tefecilik Suçu (2. Baskı, Seçkin Yayınevi 2017) 163. 


\section{MANEVI UNSUR BAKIMINDAN}

Blokzincir üzerinden borç verme işlemine onay vererek bu işlemin gerçekleşmesini sağlayan kullanıcıların eylemlerinin "banka gibi faaliyet gösterme" kapsamında değerlendirilebilmesi için bu eylemi bilerek ve isteyerek gerçekleştirmiş olmaları gerekir. Bunun anlamı bu işlemi gerçekleştirenlerin bu borç verme işlemine onay vererek ilgili akıllı kontratın banka gibi faaliyet gösterdiğinin farkında olmaları ve yine de buna rağmen bunu gerçekleştirmeleridir. Burada ortaya çıkan en önemli sorunlardan bir tanesi, bu işleme onay veren kullanıcıların bütün dünyaya yayılmış olmalarıdır. Dolayısıyla bu işleme katılan her kullanıcının bu tür bir eylemin bankacılık gibi faaliyet gösterme anlamına geldiğini bilmesi mümkün olmayabilir. Çünkü merkeziyetsiz finansın bankacılığa alternatif bir sistem olduğunun farkında bile olmadan bu sisteme dahil olan katılımcılar dahi söz konusu olabilir. Ancak buna rağmen bu tür teknik ve çetrefilli bir sisteme katılan kişinin bu sistemin içeriksel açıdan taşıdığı anlamı bilmediğini söylemek oldukça zordur. Şayet gerçekten bu faaliyetin banka gibi faaliyet gösterme anlamını taşıdı̆̆ını bilmiyorsa en azından olası kastla hareket ettiği kabul edilebilir ${ }^{89}$. Bu kişinin hiç sorgulamadan bu sisteme dahil olup bu denli teknoloji bilgisi gerektiren sisteme dahil olabilecek bilgisi bulunmasına karşın bu sistemde onay işlemi yapmanın ne anlama geldiğini bilmemesi pek mümkün gözükmemektedir.

\section{HUKUKA AYKIRILIK BAKIMINDAN}

Bu konuda araştırılması gereken diğer bir ihtimal ise blokzincir üzerinden borç verme işlemine katılan bir kullanıcının bu faaliyetin bir banka gibi faaliyet gösterme anlamına geldiğini bilmesine rağmen bunun bir hukuka uygunluk sebebi ile hukuka uygun hale geldiğini düşünmesidir. Örneğin bu kullanıcıların bir kanun ile bu işlemlere izin verildiğini düşünüyor olmaları mümkündür. Ya da merkeziyetli finans araçlarının ekonomik sisteme bir saldırı niteliği taşıdığını; bankacılık sisteminin ekonomik sistemi çökerten bir yapı olduğunu ve bu nedenle ekonomik sistemin bu saldırılara karşı korunabilmesi için merkeziyetsiz finans araçlarının kullanılması gerektiğini düşünerek adeta meşru savunma kapsamında hareket ettiklerini düşünüyor olabilirler.

Blokzincir üzerinden borç verme faaliyetine katılan kişilerin, bu davranışlarının, bankaların ekonomik sisteme bir saldırı teşkil ettiğini ve bankalara karşı merkeziyetsiz finans araçları ile ekonomik düzeni savunmak amacıyla meşru savunma kapsamında hareket ettiklerini düşünmeleri durumunda öncelikle ortada gerçekten haksız bir saldırının bulunup bulunmadığı incelenmelidir. Kanımızca global toplumdaki kimi kesimler bankaların ekonomik düzeni talan eden ve dünyanın büyük bir kesiminin fakirleşmesine yol açan kuruluşlar olduğu düşüncesinde olsalar dahi bu yaklaşım, bankaların faaliyetlerinin haksız bir saldırı niteliği taşıdığını söylemek için yetersizdir ${ }^{90}$. Çünkü

89 Bu durumda failin suçun oluşmasına karşı kayıtsız kaldığı söylenebilir. Kayıtsızlık hakkında bkz. Detlev SternbergLieben and Frank Peter Schuster, 'StGB $\$ 15$ Vorsätzliches und fahrlässiges Handeln' in Albin Eser (ed), Schönke/ Schröder Strafgesetzbuch Kommentar (30th edn, Beck 2019) 82; Rudolf Rengier, Strafrecht Allgemeiner Teil (6th edn, Beck 2014) 105; Ali Emrah Bozbayındır, Olası Kast Kavramı ve Sinırları (Adalet 2018) 317 vd.

90 Hukuk kurallarının izin verdiği bir faaliyete karşı meşru savunmada bulunmak mümkün değildir. Bkz. Johannes Wessels, Werner Beulke and Helmut Satzger, Strafrecht Allgemeiner Teil, (49 $9^{\text {th }}$ edn, Müller 2019) 162; Rengier (n 89$) 147$ - 148. 
bankalar kuruldukları ülkelerin resmi otoritelerinin iznini alarak faaliyet gösteren kuruluşlardır. $\mathrm{Bu}$ bakımdan bankaların etkin olduğu kapitalist düzenin ekonomik anlayışı kimi kesimlerce benimsenmiyor ve saldırgan görülüyor olsa dahi hukuki açıdan bankaların faaliyetlerinin ekonomik düzene ya da toplumdaki bireylere bir saldırı olarak nitelenmesi mümkün değildir. Dolayısıyla merkeziyetsiz finans araçları kullanılmak suretiyle borç verme faaliyetine katılan kişilerin meşru savunma kapsamında hareket ettiklerini söyleyebilmek mümkün gözükmemektedir.

Kaldı ki meşru savunmanın söz konusu olabilmesi için gerçek bir kişiden kaynaklanan bir saldırının bulunması gerekir. Buradaki meselede ise bankaların faaliyetlerinin bir gerçek kişinin faaliyeti olarak kabul edilebilmesi mümkün değildir. Bunun yanı sıra meşru savunmanın zorunlu olması koşulunun ${ }^{91}$ bir gereği olarak bu yola istisnai durumlarda başvurulabilmesi bakımından da merkeziyetsiz finans araçlarının bankacılık sistemine karşı bir meşru savunma olarak değerlendirilebilmesi mümkün değildir ${ }^{92}$.

Şayet bu tür faaliyetlere izin veren bir kanun ya da düzenleme bulunduğunu düşünüyorlar ve bu nedenle eylemlerinin hukuka uygun olduğundan hareketle bu işlemleri gerçekleştiriyorlarsa bu durumda hukuka uygunluk sebeplerinin koşullarında değil hukuka uygunluk sebeplerinin varlığında hataya düşmüş olurlar ${ }^{93}$. Çünkü aslında var olmayan bir hukuka uygun sebebinin var olduğunu düşünerek hareket etmişlerdir. Diğer bir deyişle fail hukuka uygunluk sebebinin normatif yönü hakkında hataya düşmüştür ${ }^{94}$. Bu durumda aşağıda ele alacağımız haksızlık hatasına düştükleri söylenebilir.

\section{HAKSIZLIK BILINCI (KUSUR) BAKIMINDAN}

Blokzincir üzerinden borç verme faaliyetinin Bankacılık Kanunu m. 150'deki suç tipinin kapsamına girip girmediği bakımından son olarak, kusur kavramı dahilinde özellik gösterebilecek haksızlık bilinci bakımından bir değerlendirme yapılması da gerekir.

Haksızlık bilinci, failin işlediği eylemin haksızlık teşkil ettiği; diğer bir deyişle eyleminin hukuk düzeni ile çatıştığı konusunda taşıdığı bilinçtir. Bu kavram kasttan ayrı bir anlam taşımaktadır. Gerçekten kast, suçun kanuni tanımındaki maddi unsurların bilinmesi ve istenmesi iken (failin

91 Demirbaş (n 78) 300; Artuk, Gökcen, Alşahin ve Çakır (n 78) 503; Özgenç (n 78) 373; Özbek, Doğan ve Bacaksız, (n 78) 307 - 308; Koca ve Üzülmez (n 78) 283; Hakan Hakeri, Ceza Hukuku Genel Hükümler, (22. Baskı Adalet 2019) 333; Akbulut (n 78) 489; Fahri Gökçen Taner, 'Türk Ceza Hukukunda Meşru Savunma', (2010) 5 (12) Ceza Hukuku Dergisi 219, 232; Fatih Birtek, Ceza Hukuku Genel Hükümler Temel Bilgiler (6. Bask1 Adalet Yayınevi 2018) 271; Muharrem Özen, Öğreti ve Uygulama Işı̆̆ında Ceza Hukuku Genel Hükümler, (2. Baskı, Seçkin 2018), 507.

92 Ticari meşru savunmanın bu nedenle mümkün olamayacağı görüşü için bkz. Pierre-Henri Bolle, 'Ticari Meşru Savunma' (çev. Güçlü Akyürek) (2011) 2010/1 Galatasaray Üniversitesi Hukuk Fakültesi Dergisi Prof. Dr. Köksal Bayraktar’a Armağan 151, 158.

93 Detlev Sternberg-Lieben and Frank Peter Schuster, 'StGB $₫ 16$ Irrtum über Tatumstände’ in Albin Eser (ed), Schönke/ Schröder Strafgesetzbuch Kommentar (30th edn, Beck 2019) kn. 24; Özbek, Doğan ve Bacaksız (n 78) 426 - 427; Koca ve Üzülmez (n 78) 370; Akbulut (n 78) 607. 
iradesi); haksızlık bilinci failin, eylemini hukuki açıdan değerlendirmesi ve bu doğrultuda eylemini işlemesidir (failin iradesini oluşturan süreç) ${ }^{95}$.

$\mathrm{Bu}$ noktada blokzincir üzerinden borç verme işlemine katılan ve onay verme işlemi yaparak bu faaliyetin gerçekleşmesini sağlayan her katılımcı bu eylemin hukuk düzeni ile çatışma içinde olacağını düşünmeyebilir. Özellikle merkeziyetsiz finans araçları henüz çoğu ülkede hukuki bir düzenlemeye tabi olmadığı için bu faaliyetleri gerçekleştiren kişiler bu işlemlerin hukuka aykırı olmadığını düşünebilir. Gerçekten de açıkça yasaklanmadığı sürece bütün davranışların serbest olduğunun kabul edildiği gelişmiş hukuk düzenlerinde merkeziyetsiz finans kullanıcılarının da bu düşüncede olmaları mantık dışı değildir ${ }^{96}$. Bu bakımdan henüz merkeziyetsiz finans araçları ile ilgili hukuki bir düzenleme yapılmamış olduğu bilgisi hemen hemen herkes tarafından bilinen bir gerçeklik olduğu için bu tür davranışların suç olarak düzenlenmediğinin düşünülmesi haksızlık hatası olarak kabul edilebilir. Fakat TCK m. 30/ 4, haksızlık hatasını hukuki bir sonuç doğurabilmesi için kaçınılmaz nitelik taşıması gerektiğini düzenlediğinden faillerin bu konudaki hatalarının kaçınılmaz nitelikte olup olmadığı da ayrıca incelenmelidir. Haksızlık hatasının kaçınılmaz nitelik taşıyıp taşımadığının tespitinde öncelikle failin gerçekleştirdiği faaliyetin profesyonel bir faaliyet alanı olup olmadığı araştırılır. Eğer failin eylemi, profesyonel bir faaliyet olarak özel bilgi gerektiren alana mahsus ise artık failin haksızlık hatasının kaçınılmaz nitelik taşımadığı çoğunlukla kabul edilmektedir ${ }^{97}$. Ancak özellikle Alman Federal Yüksek Mahkemesi profesyonel olarak icra edilen bir faaliyete ilişkin yanlış bilginin ya da güncel bilgi eksikliğinin kaçınılabilir hata teşkil edeceğini, çekirdek ceza hukuku denilen temel ceza kanunundaki suçlar bakımından kabul etmektedir. Dolayısıyla eğer somut olaydaki suç tipi temel ceza kanunundaki suçlardan değilse bu durumda somut olayın özelliklerine göre failin kaçınılmaz haksızlık hatasından faydalanmasının mümkün olduğunu karara bağlamaktadır ${ }^{98}$.

Blokzincir üzerindeki akıllı kontratlarda yapılan işlemlerin Bankacılık Kanunu m. 150’de düzenlenen suça uyup uymadığı bakımından yapılacak bir değerlendirmede öncelikle Bankacılık Kanunu’nda düzenlenen suçların temel ceza kanunumuz olan TCK dışında kalan suçlar olduğu göz önüne alınmalıdır. Bu yönüyle özellikle Alman Federal Yüksek Mahkemesi’nin içtihatları da göz önüne alınarak bir değerlendirme yapıldığ borç verme işlemlerine onay veren katılımcıların, bu eylemlerin haksızlık teşkil ettiği hususunda düştükleri hatanın kaçınılabilir hata olarak kabul edilme ihtimali bulunmaktadır ${ }^{99}$. Fakat bu faaliyeti gerçekleştiren kullanıcıların profesyonel oldukları her zaman söylenemese dahi özel bilgi gerektiren

95 Neslihan Göktürk, Haksızlk Yanılgısının Ceza Sorumluluğuna Etkisi, (Seçkin 2016) 23 vd.; Serkan Meraklı, Ceza Hukukunda Kusur, (2. Baskı, Seçkin 2020) 46.

96 Burada bu eylemlerin Bankacilık Kanunu m. 150/1 kapsamında ya da TCK m. 241 kapsamında yasaklandığı düşünülebilir. Fakat burada ifade edilmek istenen husus merkeziyetsiz finans işlemlerinin açıkça zikredilerek yasaklandığına dair net bir düzenlemenin bulunmuyor olmasıdır.

97 Merakl1, 'Kusur' (n 95) 83 - 85; Johannes Lamsfuß, 'Zur Vermeidbarkeit eines Verbotsirrtums bei Geschäftsleuten Besondere Erkundigungspflichten und Pflicht zur Aktualisierung' (2021) 8 Neue Zeitschrift für Wirtschafts - Steuer - und Unternehmensstrafrecht 325, 328.

98 BGH, Urteil vom 18.11.2020, 2 StR 246/ 20 (Neue Zeitschrift für Wirtschafts-, Steuer - und Unternehmensstrafrecht, 8/ 2021, 325).

99 Yan ceza hukuku olarak da isimlendirilen TCK dışında kalan suçlar bakımından kaçınılabilir hatanın söz konusu olabileceği ile ilgili olarak bkz. Göktürk (n 95) 39 - 40. 
bir faaliyet alanında hareket ettikleri unutulmamalıdır. Kanımızca bu onay verme işlemlerinin haksızlık teşkil ettiği kabul edildiği takdirde onay verme işlemini gerçekleştiren kullanıcıların bu eylemlerin Bankacılık Kanunu m. 150/ 1'de düzenlenen "izinsiz bankacılık faaliyetinde bulunma” suçunu oluşturabileceğini öngörmeleri çok mümkün değildir. Çünkü merkeziyetsiz finans alanında özel bir hukuki düzenlemenin henüz yapılmamış olmasından ötürü bu alanda hareket etmenin serbest olduğunun düşünülmesi ${ }^{100}$; Bankacılık Kanunu ile düzenlenen alanın merkeziyetli finans araçlarına özgü olduğunun düşünülmesi ve bu alanda hukukçuların dahi tam bilgi sahibi olduğunun henüz söylenememesi karşısında bu işlemleri gerçekleştiren kişilerin kaçınılmaz haksızlık hatası kapsamında hareket ettiklerinin kabulü gerekir.

Öte yandan merkeziyetsiz finans alanında gerçekleştirilen işlemler global düzeyde olup bir borç verme işlemine onay veren onbinlerce kullanıcı çoğu zaman tüm dünyaya dağılmış durumda olmaktadır. Bu nedenle onay verme işlemini yapan kullanıcılar, bu işlemler kendi ülkelerinde hukuken düzenlendiği için ya da en azından yasaklanmadığı için bütün dünyada böyle sanabilirler. Ya da diğer bir gerçeklik de kullanıcıların bu işlemlerin hukuki durumunu bütün dünya çapında araştırmaları mümkün değildir. Diğer bir ihtimal de kullanıcıların, borç verme işlemine onay verdikleri kişinin hangi ülkede olduğunu bilmeleri mümkün değildir. Bu nedenle de kullanıcıların o ülkedeki yasal durumu bilmeleri kendilerinden beklenmemelidir. Bu sebeple özellikle merkeziyetsiz finans araçlarının global düzeyde gerçekleștirilen ve sınır gözetmeyen işlemlere olanak tanımasından ötürü bu alanda diğer ülkelerde yapılan düzenlemeleri ve hukuki durumu bilmeyen kullanıcıların kaçınılmaz haksızlık hatası içinde hareket ettikleri kabul edilmelidir.

Tüm bunların yanı sıra pek çok kişi tarafından kullanılan bir akıllı kontratı kullanan bir kişi, her ne kadar bu alanda bir hukuki düzenleme bulunmuyor olsa dahi bunun pek çok kişi tarafından kullanılmakta olduğunu ve bu kullanıcıların haklarında hiçbir hukuki yaptırım uygulanmadığını düşünerek bu işlemlere katılabilir. Bu durumda da tıpkı metruk hükümler bakımından geçerli olan hukuki durum ortaya çıkmaktadır ${ }^{101}$. Toplumda serbest olduğu gözlemlenen bir davranışı bu düşünce ile gerçekleştiren bir fail kaçınılmaz bir haksızlık hatasına düşmüş sayılabilmelidir.

\section{SUÇUN ÖZEL GÖRÜNÜŞ ŞEKILLERI}

\section{A. TEŞEBBÜS}

Blokzincir üzerinden borç verme eyleminin bir an için izinsiz bankacılık faaliyetinde bulunma suçunu oluşturduğu kabul edildiği takdirde teşebbüs bakımından özellik gösteren hal, borç verme işlemine onay veren kullanıcıların onay verdikleri işlemin sistem tarafından onaylanmaması durumudur. Bu oldukça istisnai bir durum olup işlem gereken bütün koşulları (örneğin borç alacak kişinin önceden teminat yatırması gibi) sağlıyor olmasına rağmen örneğin yeterli sayıda kullanıcı

100 Hukuki durumun objektif olarak belirgin olmadığı durumlarda; diğer bir deyişle hukuk düzeninin, davranışın yasak olup olmadığı konusunda henüz kesin bir kural koymadığı durumlarda failin hatasının kaçınılmaz nitelikte olduğu söylenebilir. Bkz. Göktürk (n 95) 166.

101 Metruk hükümler hakkında bkz. Birtek (n 91) 27. 
tarafından onaylanmadığ için sistem tarafından onaylanmaz ise bu durumda bu işleme onay veren kullanıcıların eylemlerinin teşebbüs aşamasında kaldığı düşünülebilir. Ancak bunun oldukça uç bir örnek olduğu da gözden uzak tutulmamalıdır. Ayrıca onay verme işlemini gerçekleştiren faillerin haksızlık hatasından faydalanmalarının mümkün olduğu da göz önünde bulundurulmalıdır.

\section{B. ÍSTTIRAK}

Blokzincir üzerinde kurulan akıllı kontratlar üzerinden bir borç verme işleminin gerçekleşebilmesi için bu işleme çok sayıda kullanıcının onay vermesi gerektiği için bu tür eylemler aslında çok failli suç niteliğini taşır. Çok failli suçların en büyük özelliği, bu konuda suç tipinde bir açıklık bulunmasının ve suçun unsurlarında bu hususun açıkça sayılmasının zorunlu olmasıdır ${ }^{102}$. Ancak banka gibi faaliyet gösterme eyleminin kanuni tanımında bu yönde bir açılılk bulunmamaktadır. Bankacılık Kanunu m. 150/1'deki suç, çok failli suç olarak düzenlenmemiştir. Bankacıllk Kanunu’nun yürürlüğe girdiği dönemde henüz merkeziyetsiz finans araçlarının ortaya çıkmamış olmasından ötürü merkeziyetsiz finans araçları göz önüne alınmamıştır.

Öte yandan blokzincir üzerinden borç verme faaliyetinin yine de Bankacılık Kanunu m. 150/1'deki suç tipinin kapsamında kaldığl; çünkü bu suç tipi her ne kadar çok failli suç olarak düzenlenmemiş olsa da bu suçun birlikte faillik ya da yan faillik ile işlenmesinin mümkün olduğu öne sürülemez. Çünkü blokzincir üzerinden borç verme işlemine onay veren her kullanıcı, diğer onay veren kullanıcılar ile bir irtibat içerisinde olmayıp onay veren her kullanıcı bunu bireysel bir karar olarak uygulamakta ve diğer kullanıcıların bu işleme onay verip vermeyeceklerini bilmemektedir. Bu bakımdan örneğin MakerDAO akıllı kontratının kullanıcılarından bir kişinin bir işleme onay vermesi hem o işlemin gerçekleşmesi için yeterli değildir hem de bu kullanıcı bu onay işlemini diğer kullanıcılardan bağımsız ve özgür olarak gerçekleştirmekte; diğer kullanıcıların iradelerinin ne yönde olacağını bilmemektedir. Kaldı ki kullanıcıların birbirleri ile neredeyse hiçbir bağlantıları bulunmayıp her biri dünyanın çeşitli ülkelerine yayılmış durumdadır. Dolayısıyla bir akıllı kontratın kullanıcılarının iştirak iradesi kapsamında hareket ettiğinin söylenebilmesi mümkün gözükmemektedir ${ }^{103}$.

Azmettirme bakımından ise şunlar söylenebilir. Şayet blokzincir üzerinden kullanıcıların bu işlemleri yapması kendilerinden istenmiş ve kendileri de bu doğrultuda bu onay verme işlemlerini gerçekleştirerek borç verme faaliyetinin oluşmasını sağlamışlarsa artık burada azmettirmenin bulunduğu söylenebilir. Fakat bunun için bu eylemlerin izinsiz bankacılık faaliyetinde bulunma suçunun unsurlarını oluşturduğunun söylenebiliyor olması gerekir. Benzer bir açıklama yardım etme eylemleri bakımından da geçerlidir.

Benzer bir değerlendirme yan faillik bakımından da geçerlidir. Bankacılık Kanunu m. 150/1'deki suçun merkeziyetsiz finans faaliyetleri ortaya çıkmadan önce düzenlenmesine rağmen bu suç tipinin bu faaliyetleri de kapsayacağı; örneğin blokzincir üzerinden borç verme faaliyetinde Bankacılık

102 Özbek, Doğan ve Bacaksız (n 78) 507 - 508; Hakeri (n 91) 525, 526. Ayrıca bkz. Özgenç (n 78) 536.

103 İştirak iradesi hakkında bkz. Özgenç (n 78) 555; Özbek, Doğan ve Bacaksız (n 78) 520; Hakeri (n 91) 541; Koca ve Üzülmez (n 78) 455; Akbulut (n 78) 697. 
Kanunu m. 150/1'deki izinsiz bankacılık faaliyetinde bulunma suçunun yan faillik biçiminde ortaya çıkacağını söylemek mümkün değildir. Çünkü bir suçun yan faillik şeklinde ortaya çıkabilmesi için; öncelikle bu suç tipinin tek bir fail tarafından da işlenebilir bir nitelikte olması; fakat somut olayda birbirinden habersiz birden fazla failin bu suçun hareketini gerçekleştirmesi gerekir. Ancak merkeziyetsiz finans işlemleri ve özellikle blokzincir üzerinden borç verme faaliyeti göz önüne alındığında bu işlemlerin gerçekleşebilmesi için ilgili akıllı kontrat üzerinde çok sayıda kullanıcının onay verme işlemi yapması gerekmektedir. Bu nedenle blokzincir üzerinden borç verme işleminin Bankacılık Kanunu m. 150/1'deki suçu oluşturabilmesi için mutlaka pek çok kişinin onayı gerekir. O halde bu eylemin yan faillik kapsamına sokulması mümkün olmayıp mutlaka cezalandırılmak isteniyor ise ayrı bir suç tipi olarak çok failli suç niteliğinde kaleme alınması gerekmektedir. Bu değerlendirme kanunilik ilkesinin zorunlu bir sonucudur.

\section{c. IÇTiMA}

Birden fazla borç verme eylemi, içtima bakımından özellik gösteren bir durum olarak karşımıza çıkar. Şayet bu eylemlerin izinsiz bankacılık faaliyetinde bulunma suçunu oluşturduğu bir an için kabul edildiği takdirde değişik zamanlarda aynı eylemin aynı kişiye karşı işlenmesi durumunda zincirleme suç hükümleri uygulanacaktır. TCK m. 43/1'de mağduru belli bir kişi olmayan suçlar bakımından da zincirleme suç hükümlerinin uygulanabileceği düzenlenmektedir.

Öte yandan bu eylemlerin izinsiz bankacılık faaliyetinde bulunma suçu ve tefecilik suçu arasında bir içtima ilişkisi yaratıp yaratmadığına da değinilmelidir. Yukarıda tefecilik suçu bakımından yapılan kıyaslama da göz önüne alındığı takdirde kanımızca her iki suç arasında bir içtima ilişkisi bulunmamaktadır. Bu suçların oluşmaları birbirinden farklı unsurları gerektirmekte olup bir eylemin aynı anda her iki suçu oluşturabilmesi mümkün değildir. Fakat öğretide bu iki suç arasında özelgenel norm ilişkisi bulunduğunu savunan görüşlerin bulunduğu da belirtilmelidir ${ }^{104}$.

\section{MEVDUAT KABUL ETME}

\section{GENEL OLARAK}

Mevduat kabul etme merkeziyetli finans araçlarından biri olarak, bankaların talep edildiği zaman ya da belli bir zaman dilimi sonunda müşterilerine geri vermek üzere müşterilerinden para toplamaları ve belirli koşullar altında bu para için faiz ödemesi yapmasıdır ${ }^{105}$. Merkeziyetsiz finans alanında ise staking ve likidite madenciliği (yield farming), mevduat kabul etme faaliyetine benzemektedir. $\mathrm{Bu}$ yönüyle bu faaliyetlerin Bankacılık Kanunu m. 150/1'deki izinsiz bankacılık faaliyetinde bulunma suçu bakımından mevduat kabul etme olarak değerlendirilip değerlendirilemeyeceği ele alınmalıdır.

104 Özbek, Doğan ve Bacaksız, (n 85) 952.

105 Gündoğdu (n 75) 31; Akgün (n 75) 17. Ayrıca bkz. Mehmet Vurucu ve Mustafa Ufuk Arı, Güncel Gelişmeler Işı̆̆ında Bankacılık Ürün ve Hizmetleri (2. Baskı, Seçkin 2017) 37 vd. 
Staking faaliyetine baktığımızda özellikle bir kripto para borsasına ya da bir internet sitesi üzerinden bir stake etme sistemine kripto para kilitlendiğinde bu sistemden düzenli olarak pasif gelir adı verilen gelir elde edilmektedir. Bunun anlamı esasında kripto paranın ödünç verilmesi ve belirli bir süre sonunda geri alınabilmesidir. Bunun karşılığında da gelir elde edilmiş olunmaktadır. Bu sistemde önem arz eden nokta stake edilerek bir sisteme kilitlenip konulan kripto paraların belirli bir kişi ya da kuruma teslim edilmiş sayılıp sayılmayacağıdır. Çünkü mevduat kabul etme faaliyeti bakımından bu eylemi gerçekleştiren bir kişi ya da bir kurum söz konusu olmalıdır. Özellikle çeşitli internet siteleri üzerinden hizmet veren stake etme sistemleri bu bakımdan bir kurum olarak kabul edilebilir. Ancak henüz hukukumuzda merkeziyetsiz finans araçlarının ve buna bağlı olarak stake etme faaliyetlerinin hukuki bir düzenlemeye kavuşmamış olmasından ötürü bu kurumlar BDDK'dan, SPK'dan ya da T.C. Hazine ve Maliye Bakanlığı’ndan herhangi bir izin almak yükümlülüğü altında değildir. Bu sebeple de şu an için izinsiz ve ruhsatsız şekilde staking faaliyetleri gerçekleştirilebilmektedir. Kanımızca kripto paraların bir kripto para borsasına ya da bir sisteme kilitlenmesi ve belirli süreler sonunda ya da talep edildiği takdirde herhangi bir zaman geri çekilebiliyor olması; ayrıca sistemde kilitli tutulduğu süre ile paralel olarak bir gelir imkanı sağlaması göz önünde tutulduğunda, bu faaliyetin bankaların tekel olarak ellerinde tuttukları mevduat kabul etme faaliyetinden farklı bir anlam taşıdığı söylenemez. Bu noktada stake edilen kripto paralardan elde edilen gelire mevduat faizi yerine, "pasif gelir” adının verilmesinin bir şeyi değiştirmeyeceği açıktır. Çünkü içeriksel anlamda bu faaliyet de bir faiz getirisi niteliğindedir.

\section{MADDI UNSUR}

\section{A. SUÇUN KONUSU}

Staking işleminin Bankacılık Kanunu m. 150/ 1'deki “izinsiz bankacılık faaliyetinde bulunma” suçunu oluşturması için suçun konusu bakımından eylemin bu suç tipine uyuyor olması gerekir. Bankacılık Kanunu m. 150/1'deki suçun konusu suç tipinde açıkça belirtilmemiştir. Ancak kanunkoyucu Bankacılık Kanunu m. 3’te mevduat kavramını tanımlamıştır. Buna göre "Mevduat: Yazılı ya da sözlü olarak veya herhangi bir şekilde halka duyurulmak suretiyle ivazsız veya bir ivaz karşıllğında, istendiğinde ya da belli bir vadede geri ödenmek üzere kabul edilen parayı,...ifade eder.” Kanunun 3'üncü maddesinde bankaların kabul edeceği mevduatın konusunu sadece para oluşturabileceği için staking konusunu oluşturan kripto paralar bu tanım kapsamında kalmamaktadır. Gerçekten Para kavramı, devlet ya da devletin yetkili kıldığı bir makam (örneğin Merkez Bankası) tarafından onaylanan ve genel kabul zorunluluğuna bakılmaksızın ödeme aracı olarak tedavüle konulan değer taşıyıcısıdır ${ }^{106}$. Bu tanım karşısında kripto paraları, para tanımının kapsamında kabul etmek mümkün değildir. Ayrıca 6493 sayılı Ödeme ve Menkul Kıymet Mutabakat Sistemleri, Ödeme Hizmetleri ve Elektronik Para Kuruluşları Hakkında Kanun m. 3/ 1 - (ç)'de yapılan elektronik para tanımına da uymamaktadır ${ }^{107}$. Çünkü kripto paralar elektronik para ihraç eden kuruluş tarafından kabul edilen

106 Meraklı (n 42) 732; Bozkurt Yüksel (n 34) 186; Balcı (n 13) 211; Engin (n 35) 4 vd.

1076493 sayılı Ödeme ve Menkul Kıymet Mutabakat Sistemleri, Ödeme Hizmetleri ve Elektronik Para Kuruluşları Hakkında Kanun m. 3/ 1 - (ç)'ye göre "Elektronik para: Elektronik para ihraç eden kuruluş tarafindan kabul edilen fon karşıllğ̆ ihraç edilen, elektronik olarak saklanan, bu Kanunda tanımlanan ödeme işlemlerini gerçekleștirmek için kullanılan ve elektronik 
fon karşılığı ihraç edilme özelliğini taşımamaktadır ${ }^{108}$. BDDK da 25.11.2013 tarihli duyurusu ile, bitcoinin 6493 sayılı Kanun kapsamına girmediğini ifade etmiştir ${ }^{109}$.

$\mathrm{Bu}$ açıllamalardan hareketle kripto paralar her ne kadar bir değer sembolize etseler dahi para kavramının kapsamına girmemektedir. Mevduat kabul etme eyleminin konusunu da Bankacılık Kanunu m. 3’te yapılan tanım uyarınca sadece para oluşturabilecektir. Bankacılık Kanunu m. 150/1'ye göre kripto paralar mevduat verme faaliyetine konu edilemeyeceğine göre kanunilik ilkesi gereğince kripto paranın stake edilmek suretiyle bir sisteme kilitlenmesi ve bunun karşılığından kullanıcıların gelir elde etmeleri durumunda Bankacılık Kanunu m. 150/1'deki izinsiz bankacılık faaliyetinde bulunma suçunun konu unsuru gerçekleşmediği için suç oluşmayacaktır.

Eğer kanunkoyucu staking ve likidite madenciliği gibi faaliyetleri suç saymak istiyorsa kanunilik ilkesi gereği bunlar için mutlaka ayrı bir suç tipi oluşturmakla yükümlüdür. Fakat kanımızca bu tür faaliyetlerin suç olarak düzenlenmesi, büyük bir değişimden geçen finans araçlarının gelişiminden ülkemizin mahrum kalmasına yol açacağı için bu tür bir suç ihdası hem ekonomik hayatın dinamiklerini engellememek adına hem de ceza hukukunun son çare olması özelliği karşısında yerinde olmayacaktır.

\section{B. FAiL}

Staking faaliyetinin Bankacılık Kanunu m. 150'de düzenlenen "izinsiz bankacılık faaliyetinde bulunma” suçunu oluşturup oluşturmadığı incelendiğinde, özellikle kripto para borsaları ya da internet siteleri üzerinden hizmet veren staking sistemlerinin organ ve temsilcilerinin bu suçun faili olacağı söylenebilir. Çünkü bu kurumlar staking faaliyetine izin vererek açıkça mevduat kabul etme işlemi gerçekleştirmektedirler. Ancak bu noktada özellikle Türkiye'de faaliyet gösteren kripto para borsalarının staking hizmeti vermediği gözlemlenmektedir. Örneğin şu an dünyanın en büyük kripto para borsası olarak bilinen Binance borsasının Binance TR isimli Türkiyede hizmet veren uygulaması staking hizmeti sunmamaktadır. Aynı durum Türkiye'de kurulu diğer kripto para borsalarında da görülmektedir. Ancak pek çok global kripto para borsası bulunduğu için yurtdışında hizmet veren bir kripto para borsasının uygulamasına üye olunarak bu işlem Türkiye’den de yapılabilmektedir. $\mathrm{Bu}$ durumda yurtdışında kurulu olan bir kripto para borsası Türkiye’den bir kullanıcısına bu hizmeti sunduğu için "izinsiz bankacılık faaliyetinde bulunma” suçu kısmen Türkiyede işlenmiş sayılacağından ${ }^{110}$ Bankacılık Kanunu m. 150/1'deki suçun fail unsuru oluşmuş olmakta ve bu kripto para borsasının organ ve temsilcilerinin sorumlulukları suçun diğer unsurları oluştuğu takdirde

para ihraç eden kuruluş dışındaki gerçek ve tüzel kişiler tarafından da ödeme aracı olarak kabul edilen parasal değeri,... ifade eder."

108 Bozkurt Yüksel (n 34) 207; İmamoğlu (n 2) 43 vd.

109 Bankacılık Düzenleme ve Denetleme Kurumu, 'Basın Açıklaması' (BDDK, 25.11.2013) <https://www.bddk.org.tr/ Duyuru/EkGetir/510?ekId=530> Erişim Tarihi: 12.08.2021. Ayrıca bkz. Bozkurt Yüksel (n 34) 207.

110 TCK m. 8/ 1: “...Fiilin kısmen veya tamamen Türkiye'de işlenmesi veya neticenin Türkiye’de gerçekleşmesi halinde suç, Türkiye'de işlenmişs sayllır.' Türk ceza hukukunun bu konuda karma teoriyi benimseyerek failin her halükarda Türk hukukuna göre takip edilebilmesini amaçladığı söylenebilir. Bunun eleştirisi hakkında bkz. Özbek, Doğan ve Bacaksız (n 78) $142-143$. 
söz konusu olacaktır. Bu noktada özellikle suçun konu unsurunun oluşmadığının ve bu nedenle bu eylemlerin cezalandırılmasının mümkün olmadığının yukarıda belirtildiği unutulmamalıdır.

Sorunun diğer bir boyutu ise internet siteleri üzerinden hizmet veren MyContainer, Figment Network, Stake Capital gibi ${ }^{111}$ staking sistemlerinin durumudur. Bu sistemler, kripto para borsaları kadar kurumsal olmayıp çok sayıda bu tür sistem kurulabilir ve bu sistemlerin organ ya da temsilcilerinin tespiti oldukça zor olabilmektedir. Ancak yine de maddi hukuk açısından her ne kadar bu sistemler bir yazılım üzerinden hizmet vermekte iseler de bu sistemlerin bağlı bulundukları şirketlerin organ ya da temsilcilerinin bu suçun diğer unsurlarının oluştuğu bir an için kabul edildiği takdirde suçun faili olacağı söylenmelidir.

\section{MAĞDUR}

Mağdur ile ilgili açıklamalar bakımından yukarıda "banka gibi faaliyet gösterme" eylemi bakımından yapılan açılamalar "mevduat kabul etme" eylemi bakımından da geçerlidir. Staking faaliyetinde de sisteme kripto varlık kilitleyen kişinin mağdur ya da suçtan zarar gören olarak kabul edilebilmesi mümkün değildir.

\section{EYLEM}

Eylem bakımından ise yukarıda staking faaliyetinin mevduat kabul etme ile büyük ölçüde aynı anlama geldiğini aktardık. Bir bankanın mevduat kabul etmesi ile bir kripto para borsasının ya da bir staking sisteminin bunu kabul etmesi arasında neredeyse hiç fark bulunmamaktadır. Staking işleminde de belirli bir süre için kesin bir kilitleme işlemi yapılabileceği gibi istenildiği zaman kripto paranın çekilmesi şeklinde de staking işlemi yapılabilir. İkisi arasında sadece getiri oranı bakımından bir fark oluşmaktadır. Dolayısıyla staking ile elde edilen gelirin faiz yerine "pasif gelir" olarak isimlendirilmesi içeriksel anlamda bu gelirin bir mevduat geliri olduğu gerçeğini değiştirmemektedir. Fakat yukarıda ifade edildiği üzere staking ve likidite madenciliği söz konusu olduğunda Bankacılık Kanunu m. 150/1'deki suçun konu unsuru gerçekleşmeyeceği için eylem unsurunun incelenmesi ya da oluştuğunun tespit edilmesi mümkün değildir. Çünkü eylem unsurunun oluşabilmesi için suçun konu unsuru tipe uygun olmalıdır. Bu olmadığı sürece eylem unsurunun tipe uygunluğundan bahsedilmeyecektir. Bu bakımdan suçun diğer unsurlarının incelenmesi de mümkün olmayacaktır.

\section{E. KATILIM FONU TOPLAMA}

Katılım fonu kabulü, katılım bankaları tarafından gerçek ve tüzel kişilerden toplanan ve hesaplarda tutulan para olarak ifade edilebilir ${ }^{112}$. Bu faaliyet katılım bankası olarak kurulan kuruluşların

111 Umut Sezer, 'Çağımızın pasif gelir elde etme yöntemi kripto para staking seçenekleri nelerdir?' (HWP, 30.07.2021), <https:// hwp.com.tr/cagimizin-pasif-gelir-elde-etme-yontemi-kripto-para-staking-secenekleri-nelerdir-189821> Erişim Tarihi: 17.08.2021.

112 Gündoğdu (n 75) 32; Bünyamin Er ve Yusuf Güneysu, 'Katılım Bankacılığı' iç Hasan Ayaydın ve Savaş Durmuş (edr), 
toplayacakları mevduatı ifade ettiğinden, mevduat kabul etme başlığında dile getirilen düşünceler katılım fonu toplama faaliyeti bakımından da geçerlidir. Bu nedenle katılım fonu toplama faaliyeti bakımından özellik gösteren bir husus bulunmamaktadır.

\section{SONUÇ}

Bu konuda bir değerlendirme yapmadan önce vurgulanması gereken husus Bankacılık Kanunu'ndaki düzenlemelerin ve suçların merkeziyetli finans sistemi göz önünde tutularak kaleme alındığıdır. Dolayısıyla Bankacılık Kanunu esasen finans sistemini, düzensiz ve güvensiz öznelerden arındırmak amacıyla çeşitli hükümler getirmiştir. Bankacılık Kanunu'nun amacı finans alanında yeni faaliyet türlerinin önünü tıkamak değil, sistemi hakkaniyetli bir şekilde düzene sokmaktır. Bu bakımdan son yıllarda ortaya çıkan merkeziyetsiz finans araçları bankacılık sistemine benzerlik gösterdiği ve onun yerini almaya aday olduğu için bu konuda da mutlaka bir düzenleme yapılması faydalı olacaktır. Aksi takdirde Bankacılık Kanunu'ndaki düzenlemelerin doğrudan merkeziyetsiz finans araçlarına yöneltilmesi hakkaniyetli bir yaklaşım sergilemeyecektir. Bankacılık Kanunu kaleme alınırken merkeziyetsiz finans gündemde değildi ve kanunkoyucu da bu konudaki sorunları öngörerek bir kanun yapmamıştı.

Buradan hareketleörneğin Bankacılık Kanunu m. 150/1'deki suç tipinin merkeziyetsiz finans araçlarına uygulanabilmesi mümkün gözükmemektedir. Bunun ilk sebebi yukarıda da ifade edilmeye çalışıldığı üzere Bankacılık Kanunu merkeziyetli finans araçlarının düzenlenmesi bakımından kaleme alınmış bir kanun olup bu faaliyet alanın dışında kalan ve teknolojinin gelişmesiyle birlikte ortaya çıkmış olan yeni işlem türlerine uygulanmasının adil olmayacağı düşüncesidir. Aksi takdirde kanunkoyucu hem yurtdışında gelişen teknolojilerde ülkemizin kendini geliştirmesine engel olur hem de ekonomik hayata ölçüsüz bir müdahalede bulunmuş olur. Bir eylem cezalandırılmak isteniyor ise bu eylemin bütün unsurları suç tipine uygun olmalıdır. Bankacılık Kanunu m. 150/1'de yer verilen izinsiz bankacılık faaliyetinde bulunma suçundaki "banka gibi faaliyette bulunma” eyleminin eylem unsuru merkeziyetsiz finans faaliyetlerine uyuyor olsa da özellikle faillik unsuru uymamaktadır. Kanunilik ilkesinin bir gereği olarak merkeziyetsiz finans işlemlerinin çok failli suçlar olarak işlenebileceği göz önüne alınarak merkeziyetsiz finans araçlarına özgü kanun seviyesinde bir düzenleme yapılmalıdır. Aksi takdirde kanunilik ilkesi göz ardı edilmiş olur. Yine aynı suç tipindeki "mevduat kabul etme" eylemi bakımından ise suçun konusunu sadece para oluşturabileceğinden ve kripto varlıkların da para olarak kabul edilmesi şu an için mümkün olmadığından suçun konu unsuru oluşmamaktadır. Bu nedenle de hukukumuzda staking ve likidite madenciliği eylemlerinden dolayı "izinsiz bankacılık faaliyetinde bulunma suçu”na dayalı olarak ceza verilemeyecektir.

Son olarak suç politikası bakımından merkeziyetsiz finans araçları kullanılarak gerçekleştirilen eylemlerin ceza hukuku ile yaptırım altına alınmasının gerekliliği de tartışmalıdır. 21'inci yüzyılın bir teknoloji yüzyılı olduğu göz önünde tutularak hayatın her alanında olduğu gibi teknoloji alanında ve ekonomi alanında özgün gelişmelere sırt çevrilmemelidir. Aksi takdirde kanunkoyucu

Banka ve Finansal Sistem (Ekin 2016) 59. 
eliyle durağan bir ekonomik yapı ve durağan bir toplum yapısı oluşturulur ki; bu durum oldukça olumsuz sonuçları beraberinde getirebilir. Kanunkoyucunun merkeziyetli finans alanını düzenlediği gibi merkeziyetsiz finans alanını da düzenleme hakkı bulunmaktadır. Ancak bu alanı ceza hukuku araçları ile düzenleme düşüncesi son çare olarak oldukça istisnai durumlar için değerlendirilmelidir.

\section{KAYNAKÇA}

Akbulut B., Ceza Hukuku Genel Hükümler, (6. Baskı, Adalet 2019).

Akgün A., Mevduat Sözleşmeleri (Seçkin 2020).

Artuk M. E., Gökcen A., Alşahin M. E. ve Çakır K., Ceza Hukuku Genel Hükümler, (14. Baskı, Adalet 2020).

Aytekin İnceoğlu A., 'Bankacılık Kanunu’nda Yer Alan Suçlar' (Doktora Tezi, Marmara Üniversitesi 2006).

Balcı U., 'Kripto Paraların Ceza Hukuku Boyutu ve Türk Mevzuatındaki Muhtemel Düzenlenme Yeri'(2021) 155 Türkiye Barolar Birliği Dergisi 203 - 259.

Birtek F., Ceza Hukuku Genel Hükümler Temel Bilgiler (6. Baskı Adalet Yayınevi 2018).

Bolle P.H., 'Ticari Meşru Savunma’ (çev. Güçlü Akyürek) (2011) 2010/1 Galatasaray Üniversitesi Hukuk Fakültesi Dergisi Prof. Dr. Köksal Bayraktar’a Armağan 151 - 159.

Bonset S., 'Hype um Defi: Was du über Decentralized Finance wissen musst und wie du profitierst'(t3n, 28.05.20211) <https://t3n.de/news/defi-erklaert-das-steckt-hinter-decentralized-finance-1356901/,> Erişim Tarihi: 24.05 .2021$.

Bozbayındır A.E., Olası Kast Kavramı ve Sınırları (Adalet 2018).

Bozkurt Yüksel A. E., 'Elektronik Para, Sanal Para, Bitcoin ve Linden Doları’na Hukuki Bir Bakış', (2015) 73 (2) İstanbul Hukuk Mecmuası, 173 - 220.

Çınar Ç., ‘6362 Sayılı Sermaye Piyasası Kanunu’ndaki Usulsüz Halka Arz ve İzinsiz Faaliyette Bulunma Suçları’ (Yüksek Lisans Tezi, İstanbul Üniversitesi 2019).

Demirbaş T., Ceza Hukuku Genel Hükümler, (15. Baskı, Seçkin 2020).

Dursun S., Bankacılık Düzenine Karşı İşlenen Suçlar, (Seçkin 2006).

Dülger M. V., 'Blockchain ve Hukuksal Kullanım Alanları' (2019) Hukuk ve Daha Fazlası Dergisi, 42 - 47.

Dülger M. ve Özkan O., 'Kripto Para Suçları: Kripto Para Birimlerinin Hukuki Boyutu ve Türk Ceza Kanunu Bakımından Değerlendirilmesi' (2020) Prof. Dr. Mehmet Emin Artuk’a Armağan 963 - 994.

Er B. ve Güneysu Y., 'Katılım Bankacılığı’ iç Hasan Ayaydın ve Savaş Durmuş (edr), Banka ve Finansal Sistem (Ekin 2016) $51-79$.

Espich J., 'Potenziale der Blockchain-Technologie für die Finanzindustrie in Deutschland' (Master thesis, Hochschule Landshut 2019).

Göktürk N., Haksızlık Yanılgısının Ceza Sorumluluğuna Etkisi, (Seçkin 2016).

Guggenberger N., 'Digitale Transformation in der Industrie' in Andreas Leupold, Andreas Wiebe ve Silke Glossner (eds), Münchener Anwaltshandbuch IT-Recht (4th edn, Beck 2021).

Groh G., 'Blockchain' in Klaus Weber (ed), Creifelds Kompakt - Rechtswörterbuch, (4th edn, Beck 2021) <www. beck-beckonline.de> Erişim Tarihi: 06.06.2021).

Gunnar Groh, 'Kryptowährung' in Klaus Weber (ed), Greifelds Rechtswörterbuch (26th edn, Beck 2021) <www. beck-online.beck.de> Erişim Tarihi: 19.07.2021).

Gündoğdu A., Bankacılık Hukuku, (6. Baskı, Seçkin 2019).

Gürses D., 'İzinsiz Faaliyette Bulunmak Suçu'(2012) 23(80) Bankacılar Dergisi 29 - 52.

Güven Ç., 'Bankacılık Faaliyetine İlişkin Ceza Sorumluluğu', (Doktora Tezi, Ankara Üniversitesi 2016). 
Hakeri H., Ceza Hukuku Genel Hükümler, (22. Baskı Adalet 2019).

Hohn - Hein N. and Barth G., 'Immaterialgüterrechte in der Welt von Blockchain und Smart Contract' (2018) GRUR 1089 - 1096.

Hönig M., 'Initial Coin Offering Studie zu Kryptowährungen und der Blockchain-Technologie', (Frankfurt University of Applied Sciences 2018) <https://www.frankfurt-university.de/fileadmin/standard/ Hochschule/Fachbereich_3/Kontakt/Professor_inn_en/Hoenig/20180502_Bitcoin_Studie_fra_uas_ Hoenig_V1.0.pdf> accessed 22.08.2021.

İmamoğlu D. A., Kripto Para Birimleri ve Türk Hukukunda Düzenlenmesi, (2. Bask1, Seçkin 2021).

İnci Z.Ö., Tefecilik Suçu (2. Baskı, Seçkin Yayınevi 2017).

Karakehya H., 'İzinsiz Bankacılık Faaliyetinde Bulunma Suçu' (2008) LXVI (1) İÜHFM 63 - 86.

Kaulartz M. and Matzke R., 'Die Tokenisierung des Rechts', (2018) NJW 3278 - 3283.

Koca M. ve Üzülmez İ., Türk Ceza Hukuku Genel Hükümler, (13. Bask1, Seçkin 2020).

Kumpan C., 'WpHG' in Eberhard Schwark ve Daniel Zimmer (eds), Kapitalmarktrechts-Kommentar (5th edn, Beck 2020).

Lamsfuß J., 'Zur Vermeidbarkeit eines Verbotsirrtums bei Geschäftsleuten - Besondere Erkundigungspflichten und Pflicht zur Aktualisierung' (2021) 8 Neue Zeitschrift für Wirtschafts - Steuer - und Unternehmensstrafrecht 325 - 328.

Langheld G. and Haagen C., 'Decentralized Autonomous Organizations - verbandsrechtliche Einordnung und Gestaltungsmöglichkeiten' (2021) Neue Zeitschrift für Gesellschaftsrecht $724-729$.

Meier N. and Kotovskaia A., 'Finanzmarktregulatorische, währungs - und wettbewerbsrechtliche Problemstellungen', (2021) Zeitschrift für Bank - und Kapitalmarktrecht 348 - 355.

Meraklı S., 'Parada Sahtecilik Suçu (TCK m. 197)' (2020) 26(2) Marmara Üniversitesi Hukuk Fakültesi Hukuk Araştırmaları Dergisi s. 726 - 776.

Meraklı S., Ceza Hukukunda Kusur, (2. Baskı, Seçkin 2020).

Möllenkamp S. and Guggenberger N., 'Blockchain und Kryptowährungen' in Thomas Hoern, Ulrich Sieber ve Bernd Holznagel (eds), Handbuch Multimedia-Recht (55th edn, Beck 2021).

Möllenkamp S. and Shmatenko L., 'Blockchain und Kryptowährungen' in Thomas Hoern, Ulrich Sieber ve Bernd Holznagel (eds), Handbuch Multimedia-Recht (55th edn, Beck 2021).

Mutluoğlu D., 'Kripto Para Birimleri Ve Suçtan Kaynaklanan Malvarlığı Değerlerini Aklama Suçu', (Yüksek Lisans Tezi Ankara Üniversitesi 2020).

Özbek V. Ö., Doğan K. ve Bacaksız P., Türk Ceza Hukuku Genel Hükümler, (11. Bask1, Seçkin 2020).

Özbek V. Ö., Doğan K. ve Bacaksız P., Türk Ceza Hukuku Özel Hükümler, (15. Baskı, Seçkin 2020).

Özbek V. Ö., 'Tefecilik Suçu' (2010) 14 Ceza Hukuku Dergisi 29 - 39.

Özen M., Öğreti ve Uygulama Işı̆̆ında Ceza Hukuku Genel Hükümler, (2. Baskı, Seçkin 2018).

Özgenç İ., Türk Ceza Hukuku Genel Hükümler, (16. Bask1, Seçkin 2020).

Özkardeş C.Y., 'Decentralized Finance: Was hinter dem Begriff steckt' (t3n, 11.11.2019) <https://t3n.de/news/ decentralized-finance-begriff-1216522/> Erişim Tarihi: 24.05.2021.

Rengier R., Strafrecht Allgemeiner Teil (6th edn, Beck 2014).

Schäfer U. and Eckhold T., 'Crowdfunding, Crowdlending, Crowdinvesting, Kryptowährungen und Initial Coin Offerings (ICOs)' in Heinz-Dieter Assmann, Rolf A. Schütze ve Petra Buck - Heeb (eds), Handbuch des Kapitalanlagerechts, (5th edn, Beck 2020).

Schrey J. and Thalhofer T., 'Rechtliche Aspekte der Blockchain' (2017) NJW 1431 - 1436. 
Schröder F., 'Protokoll zum 172. Bochumer Steuerseminar für Praktiker und Doktoranden vom 12. März 2021' (Kompetenzzentrum Steuerrecht 2021) <https://www.kompetenzzentrum-steuerrecht.de/MEDIEN/ publikationen/Protokoll_172._Bochumer_Steuerseminar_final.pdf?m=161.666.9816\&> accessed 12.08.2021.

Schueffel P., 'The Concise Fintech Compendium', (Fintech Vitalizing Banking 2017) <http://schueffel.biz/wpcontent/uploads/2017/09/Schueffel-2017-The-Concise-FINTECH-COMPENDIUM.pdf> accessed 23.08.2021.

Sert T., 'Sorularla Blockchain' (Bankalararası Kart Merkezi 2015) <https://bkm.com.tr/wp-content/ uploads/2015/06/Sorularlablockchain.pdf> Erişim Tarihi 30.05.2021.

Sezer U., 'Çağımızın pasif gelir elde etme yöntemi kripto para staking seçenekleri nelerdir?' (HWP, 30.07.2021), $<$ https://hwp.com.tr/cagimizin-pasif-gelir-elde-etme-yontemi-kripto-para-staking-seceneklerinelerdir-189821> Erişim Tarihi: 17.08.2021.

Sternberg-Lieben D. and Schuster F.P., 'StGB $₫ 15$ Vorsätzliches und fahrlässiges Handeln' in Albin Eser (ed), Schönke/ Schröder Strafgesetzbuch Kommentar (30th edn, Beck 2019).

Sternberg-Lieben D. and Schuster F.P., 'StGB $₫ 16$ Irrtum über Tatumstände' in Albin Eser (ed), Schönke/ Schröder Strafgesetzbuch Kommentar (30th edn, Beck 2019).

Taner F. G., 'Türk Ceza Hukukunda Meşru Savunma', (2010) 5 (12) Ceza Hukuku Dergisi 219 - 253.

Tekin E., 'Parada Sahtecilik Suçu', (Yüksek Lisans Tezi Hacettepe Üniversitesi 2019).

Tevetoğlu M., 'Ethereum Ve Akıllı Sözleşmeler' (2021) 12(1) İnönü Üniversitesi Hukuk Fakültesi Dergisi 193 208.

Vurucu M. ve Arı M.U., Güncel Gelişmeler Işı̆̆ında Bankacılık Ürün ve Hizmetleri (2. Baskı, Seçkin 2017).

Wessels J., Beulke W. and Satzger H., Strafrecht Allgemeiner Teil, (49 ${ }^{\text {th }}$ edn, Müller 2019).

Yavuz M. S., 'Ekonomide Dijital Dönüşüm: Blockchaın Teknolojisi ve Uygulama Alanları Üzerine Bir İnceleme' (2019) 4(1) Finans Ekonomi ve Sosyal Araştırmalar Dergisi 15 - 29.

Zafer H., 'Tefecilik Suçu (TCK m. 241)' (2018) 4(2) Beykent Üniversitesi Hukuk Fakültesi Dergisi 69 - 97. 